\title{
O NOVO DIREITO DAS OBRIGAÇÕES NO CÓDIGO CIVIL ALEMÃO - A REFORMA DE 2002*
}

\author{
por Carl Friedrich Nordmeier ${ }^{* *}$
}

\begin{abstract}
Introduçăo; A. 1 Os motivos da reforma - o anteprojeto, a influência européia e a realização da assim chamada "Große Lösung"; A.2 As mudanças na Parte Geral: da perturbaçăo da prestação (Leistungsstörung), sobretudo da impossibilidade do cumprimento, e da prescrição (Verjährung); B.1 As novidades na Parte Especial, sobretudo no contrato de compra e venda; B.2 A integração de leis satélites; Conclusões; Bibliografia
\end{abstract}

\section{Introdução}

Poucas codificações no mundo vivenciaram uma história tão agitada como o Bürgerliches Gesetzbuch (Código Civil - BGB) alemāo. Esta é uma das grandes obras da Codificação do Século XIX, tendo sua base científica na Pandectística alemã ${ }^{\top}$. Antes de entrar em vigor em 1 de janeiro de 1900, passou por uma fase de elaboração de 22 anos (de 1874 a 1896), na qual duas comissões criaram um código, cujo nível de abstração é bastante alto². Instalaram a divisão entre Parte Geral e Parte Especial; na primeira encontram-se regras para a aplicação das normas da segunda. Este conceito teve grande impacto em outras codificações do direito civil, que o adotaram. O Código Civil brasileiro, por exemplo, deve sua divisão em Parte Geral e Parte Especial ao BGB alemão ${ }^{3}$.

Artigo elaborado e apresentado na disciplina "Teoria Geral dos Contratos - A Nova Crise Contratual", da Pós-Gradução em Direito da Universidade Federal do Rio Grande do Sul, ministrada no Semestre 2004/2 pela Profa. Dra. Cláudia Lima Marques, a quem o autor agradece a orientaçăo e esta publicaçăo. Os agradecimentos se estendem a Augusto Jaeger Junior, pela orientaçäo adicional e pelas sugestões lingüísticas, e a Anna Luiza Trein, pela revisāo do texto.

* Acadêmico de Direito na Universidade de Heidelberg, Alemanha, em fase de preparação para a realização do Primeiro Exame do Estado. Atualmente tealiza estadia de estudos na Universidade Federal do Rio Grande do Sul.

1 MARQUES, Cláudia Lima. Cem nos de Código Civil alemão: O BGB de 1986 e o Código Civil brasileiro de 1916. Revista dos Tribunais. São Paulo: Revista dos Tribunais, v. 741, 1997. p. 12.

2 Os trabalhos no BGB/1900 analisa ZIMMERMANN, Reinhard. Schuldrechtsmodernisierung? furistenzeitung. Tübingen: Mohr Siebek, v. 4, 2001. p. 171 e seg.

3 Compare MARQUES, Cláudia Lima. Op. cit. p. 13. 
Como centro e seio ${ }^{4}$ do direito civil, o BGB sobreviveu ao fim do Império alemão, à 1. Guerra Mundial, à República de Weimar, à ditadura nazista e, com ela, à Il. Guerra Mundial e acompanhou o nascimento e crescimento da República Federal da Alemanha até hoje. A mudança de valores jurídicos e sociais no decorrer do tempo sempre exigiu reformas para adaptar a lei às exigências reais. Assim, sobretudo o direito da família sofreu modificações freqüentes ${ }^{5}$ para respeitar a transformação social dos seus institutos.

O direito comunitário tornou-se outra fonte de alta importância para reformas do BGB. Como a Comunidade Européia (C. E.) criou Diretivas que penetram o Direito Civil dos Estados-Membros, surgiu a obrigação dos EstadosMembros de adaptar sua legislação nacional às suas exigências ${ }^{6}$. Uma das mudanças mais importantes do $B G B$ nos últimos anos, a inclusão das figuras do consumidor ( $\$ 13 \mathrm{BGB}$ ) e do fornecedor ( $\$ 14 \mathrm{BGB}$ ) na Parte Geral, deu-se por causa de uma Diretiva promulgada pela Comunidade Européia ${ }^{7}$.

Com a reforma do direito das obrigações, completada pela Schuldrechtsmodernisierungsgesetz (lei para a modernização do direito das obrigaçöes) de 26 de novembro de 2001, o BGB sofreu a mais importante e abrangente ${ }^{8}$ modificação desde sua entrada em vigor, mais de cem anos atrás. Quanto à questão da importância desta reforma, a doutrina é unânime no sentido de que é impossível subestimar o seu impacto sobre os conceitos jurídicos e a realidade jurídica na Alemanha ${ }^{9}$. Analisou-se que, na área principal desta codificação, pouco ficou como era antes ${ }^{10}$ - que o direito das obrigações

- MARQUES, Cláudia Linna; WEHNER, Ulrich. Código Civil alemão muda para incluir a figura do consumidor - renasce $o_{n}$ direito civil geral e social"? Revista de Direito do Consumidor. São Paulo: Revista dos Tribunais, v. 37, 2001. p. 272.

5 MARQUES, Cláudia Lima. Cem nos de Código Civil alemão: OBGB de 1986 e o Código Civil brasileiro de 1916. Revista dos Tribunais. São Paulo: Revista dos Tribunais, v. 741, 1997. p. 34.

- Compare art. 249 do Tratado sobre a Comunidade Européia (TCE). Diretiva 93/1 3/CEE sobre cláusulas abusivas. Veja a análise profunda de MARQUES, Cláudia Lima. Nomas de proteção do consumidor (especialmente no comércio eletrônicol oriundas da Uniăo Européia e o exemplo de sua sistematização no Código Civil alemảo de 1896 - notícia sobre as profundas modificaçǒes no BCB para incluir a figura do consumidor. Revista de Direito Privado. São Paulo: Revista dos Tribunais, v. 4, 2000. p. 50 e seg.

a WITZ, Claude. Pourquoi la réforme et pourquoi s $s^{\prime}$ intéresser en France?. Revie internacionale de droit comparé. Paris: Francain, v. 54, 2002, p. 937.

9 Veja os comentários de HONSELL, Heinrich. Einige Bemerkungen zum Diskussionsentwurf eines Schuldrechtsmodernisierungsgesetzes. Juristenzeitung. Tübingen: Mohr Siebeck, v. 1, 2001. p. 18. e de BÜDENBENDER, Ulrich. Das Kaufrecht nach dem Schuldrechtsreformgesetz (Teil l). Deutsches Steuerrecht: Wochenschrift für Steuerrecht, Wirtschaftsrecht und Betriebswirtschaft. München: C. H. Beck, v, 8, 2002. p. 312 .

10 DAUNER-LIEB, Barbara. Die geplante Schuldrechtsmodernisierung - Durchbruch oder Schnellschuss?. Juristenzeitung. Tübingen: Mohr Sieheck, v. 1, 2007 . p. 9. 
foi re-escrito ${ }^{11}$ e a tradição pandectística do direito romano, definitivamente abandonada ${ }^{12}$.

HELDRICH enxerga na reforma um êxito científico impressionante que dá um rosto atual ao direito das obrigações ${ }^{13}$, e WITZ comenta que o BGB foi redinamizado para o século $X X{ }^{14}$. Ainda assim, pode-se dizer que a doutrina alemā sobre a reforma do direito das obrigações traz mais rejeição do que aprovação. Num congresso em 2000, cujo objetivo foi a análise do anteprojeto, reuniram-se especialistas de todos os ramos do direito civil alemão ${ }^{15}$. Nenhum dos referentes considerou, no seu ramo, o anteprojeto elaborado o suficiente para ser aprovado pelo legislador, mas exigiram-se mudanças mais ou menos abrangentes, dependendo do ponto de vista de cada $u m^{16}$. Ainda assim, é necessário mencionar que tinha tido também vozes críticas quanto à reforma ${ }^{17}$.

Levando em conta tudo isto e considerando que o SBrasil reformou seu direito das obrigações também ${ }^{18}$, este artigo busca - depois de relatar a história da reforma e os seus motivos - analisar as mudanças no BGB. Além de tratar dos antigos problemas solucionados pela reforma e das novas questões que surgiram com ela, quer-se mostrar os novos conceitos e as novas linhas gerais que pretendem preparar o direito civil alemão para o Século XXI. Também devem ser ouvidas as vozes críticas para ver os desafios que a jurisprudência e doutrina alemãs enfrentarão ou já estão enfrentando, aplicando e pesquisando o novo direito das obrigaçōes.

11 BRÜGGEMEIER, Gert; REICH, Norbert. Europäisierung des BGB durch große Schuldrechtsreform? Stellungnahme zun Entwurf eines Schuldrechtsmodernisierungsgesetzes. Betriebsberater. Heidelberg: Recht und Wirtschaft, v. 5, 2001 . p. 213.

12 RANIERI, Filippo. La nouvelle partie générale du droit des obligations. Revue internacionale de droit comparé. Paris: Francain, v. 54, 2002. p. 941.

13 HELDRICH, Andreas. Ein zeitgemäßes Gesicht für unser Schuldrecht. Neue furistische Wochenschrift, München: $C$. H. Beck, v. 35, 2001, p. 2523.

${ }^{14}$ WTTZ, Claude. Op. cit. p. 940.

i. Contriburam com palestras, entre outros, HUBER, ZMMMERMANN, ROTH, KÖNDGEN, PFEIFFER, MANSEL, HEß MEDICUS. Compare os relatos sobre o evento de IAKOBS, Horst Heinrich. Tagungsbericht Schuldrechstmodemisierung: Impressionen von einem Symposium. Juristenzeitung. Tubingen: Molar Siebeck, v, 1, 2001 , p. 27 e seg. ede SCHWAB, Martin. Schuldrechtsneform 2001 - Alles wird neu. Juristische Schulung. München: C. H. Bedk, v. 3, 2001. p. 311 e seg.

ig DAUNER-LIEB, Babara. Op. cit.p. 12.

17 Os críticos mais fortes formularam KNÜTEL, Rolf. Zur Schuldrechtsreform. Neue luristische Wochenschrift. München: C. H. Beck, v. 35, 2001. p. 2519 e Honsell, Heintich. Op. cit. p. $19 .{ }^{19}$ As nomas do BGB săo indicadas por parágrafos, nắo por artigos.

in Sobre o assunto, veja a análise de IAEGER UUNIOR, Augusto. Das neue brasilianische Bürgertiche Gesetzbuch und das Unternehmensrecht. Em; J AYME, Erik; SCHINDLER, Christian (Org). Portugiesisch - Weltsprache des Rechts: Studien, Referate, Gutachten zu den Rechtssystemen von Angola, Brastien, Osttimor und Portugal. Aachen: Shaker, 2004. p. 217-235. 
O trabalho divide-se em duas partes: num primeiro momento, analisam-se os motivos da reforma e as mudanças na Parte Geral do direito das obrigaçōes, que consistem, principalmente, na perturbaçāo da prestação e na prescrição (Verjährung).

Já vale lembrar que o BGB - como o Código Civil Brasileiro - divide-se em cinco livros: I. Parte Geral 11. Direito das Obrigações III. Direito das Coisas IV. Direito da Família e V. Direito das Sucessões. A reforma aqui em questão afeta somente o Livro II "Direito das Obrigações". Este livro também está divido em Parte Geral $(\$ \S 241-432)^{19}$ e Parte Especial $(\$ \S 433-853)^{20}$. É, portanto, necessário distinguir entre Parte Geral/Especial do BGB e Parte Geral / Especial do direito das obrigações. Neste texto, as duas noções referem-se sempre ao direito das obrigações, se não se encontrar uma referência expressa.

$\mathrm{Na}$ segunda parte, trata-se das novidades na Parte Especial, que se encontram, sobretudo, no contrato de compra e venda. Além disso, a integração de leis satélites, como, p. ex., a lei sobre condições gerais do contrato, no BGB é explanada.

\section{A. 1 Os motivos da reforma - o anteprojeto, a influência européia e a realização da assim chamada "Große Lösung"}

As raízes da reforma encontram-se já no ano 1978, quando o entāo Ministro da Justiça, Hans-Jochen Vogel, considerou necessária uma revisão do direito das obrigaçōes e anunciou a instalação de uma comissão ${ }^{21}$. Sob encomenda do Governo Federal, 24 pareceres sobre o assunto foram elaborados nos anos de 1981 a $1983^{22}$, e criou-se uma comissāo para a reforma em 1984. Durante seus trabalhos, ela tomou como base a United Nations Convention on Contracts for the International Sale of Goods (CISG) - convenção sobre contratos de compra e venda internacional de mercadorias, que entrou em vigor em grande parte na Alemanha em 1989. O relatório final da comissão foi apresentado em 1992 e discutido no 60 . Deutschen Juristentag, um dos mais importantes congressos jurídicos na Alemanha, em $1994^{23}$.

\footnotetext{
19 As normas do BGB são indicadas por parágrafos, não por artigos.

20 Sobre a estrutura do BGB e uma análise comparativa com o Código Civił Brasileira, confra MARQUES, Cláudia Lima. Cem nos de Código Civil alemão: O BGB de 1986 e o Código Civil brasileiro de 1916. Revista dos Tribunais. São Paulo: Revista do5 Tribunais, v. 741, 1997. p. 29 eseg.

27 Sobre os trabalhos da comissăo, ZIMMERMANN, Reinhard. Op. cit, p. 176.

22. Bibliografia abrangente sobre as pareceres em DAUNER-LIEB, Barbara. Op. cit. p. 10.

23 A maioria dos participantes do congresso se manifestou a favor das mudanças sugeridas. LORENZ, Stephan; RIEHM, Thomas. Lehrbuch zum neuen Schuldrecht. München: C. H. Beck, 2002. p. 3, ponto 3.
} 
Depois seguiu um período longo de inatividade; somente em 2000, a reforma do Direito das Obrigaçōes foi retomada. Em agosto daquele ano, o Ministério da Justiça lançou um "projeto de discussão sobre uma lei para a modernização do direito das obrigações" ${ }^{\prime 24}$. Esta reanimação surpreendente da reforma ${ }^{25}$ não se deu por causa do âmbito nacional, mas sim por obrigações oriundas do nível comunitário. Três Diretivas tiveram que ser internalizadas: a Diretiva relativa a certos aspectos da venda de bens de consumo e das garantias a ela relativas ${ }^{26}$, a Diretiva que estabelece medidas de luta contra os abusos de pagamento nas transaçōes comerciais ${ }^{27}$ e a Diretiva relativa a certos aspectos legais de serviços da sociedade de informação, em especial do comércio eletrônico, no mercado interno ("Diretiva sobre o comércio eletrônico") ${ }^{28}$. Como o prazo para a internalização da primeira esgotou em 1 de janeiro de 2002 e o direito alemão não correspondeu às suas exigências, foi necessário aplicar as mudanças exigidas.

Ofereceram-se dois caminhos para realizar a transposição ${ }^{29}$. O primeiro, chamado de "kleine Lösung" (solução pequena), consistiu em limitar-se a transformar as Diretivas em direito nacional, colocando as regras relevantes em leis especiais. A grande vantagem desta solução foi considerada o fato de que, com tanto aperto de tempo, seria methor ainda não interferir no $B G B$, mas fazer as conexões necessárias entre o Código e as leis especiais depois, sem a pressão do prazo para a internalização. Por outro lado, a solução pequena teria trazido uma separação do direito das obrigaçôes em várias fontes: o contrato de compra e venda, por exemplo, teria sido regulado pelas normas da CISG, pelas normas das leis especiais para a internalização das Diretivas, pelas normas do Código Civil e pelas normas do Código Comercial. Isto teria trazido uma difusão enorme das fontes e, com ela, teria aumentado o risco de ocorrer incoerências dentro do sistema ${ }^{30}$.

O segundo caminho, chamado de "große Lösung" (solução grande), evitou este problema. Ele combinou as mudanças necessárias oriundas do direito comunitário com o projeto de reforma já elaborado e chegou, desta maneira, a uma reforma abrangente do direito das obrigaçōes. Além disso, pretendeu

24 Diskussionsentwurf eines Schuldrechtsmodernisierungsgesetzes que compreendeu 640 páginas, sendo 164 páginas texto de lei e os demais motivos e explicações.

25 OTrO, Hansjörg. Die Grundstrukturen des neuen Leistungsstörungsrechts. Juristische Ausbildung. Berlin: De Gruyter, v. 1,2002.p.2.

26. Diretiva 1999/44/CE de 25 de maio de 1999. Journal Oficial das Comunidades Européias $L$ 171/12.

27 Diretiva 2000/35/CE de 29 de junho de 2000. Journal Oficial das Comunidades Européias $\lfloor 200 / 35$.

26. Diretiva 2000/31/CE de 8 de junho de 2000. Journal Oficial das Comunidades Européias L. 178/1.

29 LORENZ, Stephan; RIEHM, Thomas. Op. cit p. 2 , ponto 2.

30 PALM, Heinz. Die Schuldrechtsreform vor dem Hintergrund des Gemeinschaftsrechts. Zeitschrift für Rechtspolitik. München: C. H. Beck, v. 9, 2001.p. 432. Odireito das Diretivas foi um corpo absolutamente estranho para o sistema alemão, como observa WITZ, Claude. Op. cit. p. 937. 
integrar várias leis satélites no BGB. Esta solução foi sugerida pelo Ministério da Justiça no seu projeto de discussão e enfrentou críticas por parte da doutrina alemán ${ }^{3 ?}$.

Mas admitiu-se que as mudanças exigidas pelas Diretivas obrigavam a mudar, pelo menos, a Parte Especial do Direito das Obrigações; isto, em contrapartida, gerava efeitos para a Parte Geral, o que indicava uma reforma abrangente para evitar incoerências e a difusão do sistema no total ${ }^{32}$. A "solução pequena", portanto, não podia ser considerada uma solução razoável ${ }^{33}$. Além disso, usaram-se as argumentações do relatório da comissão de 1991, que expressou que o Direito das Obrigações alemão deixou a desejar em vários aspectos. Sobretudo o direito da perturbação da prestação (Leistungsstörungsrecht) foi criticado por tratar de maneira abrangente a impossibilidade da prestação (Unmöglichkeit), mas não regular o infringimento positivo do contrato (positive Vertragsverletzung), levando em consideração que, na prática, a impossibilidade da prestação é de importância muito menor que ele $^{34}$. Desta maneira, surgiu jurisprudência abrangente sobre o assunto, o que fez com que a situação jurídica já não pudesse ser analisada usando o BGB, mas foi necessário pesquisar adicionalmente as sentenças do Bundesgerichtshof (Corte Federal Alemã). Isto contradizia a idéia de um "Codex" que deve responder sozinho os problemas jurídicos para trazer mais segurança e clareza ao aplicador do direito e, desta maneira, para todos os cidadãos ${ }^{35}$. Assim, pretendeu-se codificar as figuras juridicas mais importantes desenvolvidas pela jurisprudência para aproximar, novamente, o texto de lei ao direito praticado na realidade ${ }^{36}$.

Esta idéia trouxe uma nova questão: quais figuras deviam ser codificadas? $E$, numa visão mais generalizada: a codificação traria realmente mais segurança jurídica? Argumentou-se que, p. ex., a figura da quebra objetiva da base do negócio tinha se desenvolvido "caso a caso" e tinha se tornado uma figura que, pelo menos na jurisprudência, ainda não mostrara uma coerência suficiente para a codificaçāo ${ }^{37}$.

31 Compare HONSELL, Heinrich. Die EU-Richtlinie über den Verbrauchsgüterkauf und ihre Umsetzung ins BGB. Juristenzeitung. Tübingen: Mohr Siebeck, v. 6,2001.p. $278 \mathrm{eseg}$.

32 Compare PALM, Heinz. Op. cit, p. 432.

33 DAUNER-LIEB, Barbara. Op. cit. 10.

34 Entende-se que a impossibilidade da prestação se dá pelo fato que a prestação não pode ser realizda (p. ex., por causa de força maior). O infringimento positivo do contrato descreve a situação que o devedor, ao cumptir o contrato, infere bens juridicos do credor (exemplo: Ao fornecer o produto comprado para a casa do comprador, o devedor danifica a porta).

35 MEDICUS, Dieter alertou que nâo foi possivel nem adivinhar a sentença de um tribunal usando o mero texto de lei do BCB/A900. MEDICUS, Dieter. Schuldrecht: Ein Studienbuch. Algemeiner Tejl. 13. ed. Munique: C. H. Beck, 2002. p. 23, ponto 47.

36 Compare DÄUBLER-GMELIN, Herta. Die Entscheidung für die sogenannte GroBe Lösung bei der Schuldrechtsreform. Neue Juristische Wochenschrift. München: C. H. Beck, v. 32, 2001.p. 2284. DAUNER-LIEB, Barbara. Op. cit. p. 10. WITZ, Claude. Op. cit. p. 938.

37 Compare JAKOBS, Horst Heinrich. Op. cit. p. 28. Crítico quanto à codificação WETZEL, Thomas. Das Schuldrechtsmodemisierungsgesetz - Der groBe Wurf zum 1.1.2002. Zeitschrift für Rechtspolitik. München: C. H. Beck, v.3, p. 125. 
Um outro argumento para realizar a "solução grande" foi a concorrência internacional no ramo do direito civil: o antigo sistema alemão não se mostrou como uma alternativa capaz de concorrer na Europa. Com uma modernização no sentido da comissão queria-se seguir os desenvolvimentos internacionais e abrir a chance de tomar uma posição de liderança no processo da europeização do direito privado ${ }^{38}$. Um código moderno que traz, principalmente, mais transparência é de alta importância para a praxe jurídica internacional ${ }^{39}$.

Talvez o maior problema da realização da "solução grande" tenha se dado por falta de tempo para discutir abrangentemente todos os aspectos da reforma ${ }^{40}$. Com o prazo de internalização tão curto (a Diretiva sobre a compra e venda de bens de consumo foi promulgada em 25 de janeiro de 1999 e tinha que ser internalizada até 1 de janeiro de 2002), uma parte da doutrina rejeitou a reforma proposta pelo Ministério da Justiça ${ }^{41}$. A maioria enxergou pelo menos um grande obstáculo para garantir a qualidade da reforma ${ }^{42}$.

O debate científico intensificou-se com base no projeto de discussão do Ministério da Justiça de agosto de 2000. Recebendo as críticas doutrinárias, uma nova comissão elaborou uma "Konsolidierte Fassung" (versão consolidada) do projeto ${ }^{43}$. Esta versão consolidada foi enviada ao Bundesrat como projeto de lei do Governo Federal, e, ao mesmo tempo, apresentada ao Bundestag como proposta de lei das frações SPD e Partido Verde. Isto servia para acelerar o processo de legislação.

Em vários pontos, o Bundesrat não esteve de acordo com o projeto de lei e exigiu mudanças ${ }^{44}$, o que teve como conseqüência que a comissão de Direito (Rechtsausschuss) do Bundestag elaborou mais uma versão. Esta foi aprovada

38 DÄUBLER-GMEIN, Herta. Op. cit. p. 2289. SCHMIDT-RÄNTSCH numa palestra de 13 de novembro de 2000 apud DAUNER-LIEB. Op. Cit. p. 10.

39 WWLDRCH, Andreas. Op. cit. p. 2523.

40 Isto foi destacado por HAMMEN, Horst. Zerschlagt die Gesetzestafein nicht! Wertpapiermitteilungen: Zeitschrift für Wirtschafts- und Bankrecht. Frankfurt am Main; Herausgebergemeinschaft Werpapiermitteitungen, v. 29, 2001 . p. 1359.

41 Uma posiçảo muito negativa toma KNUTEL, Rolfque afima que as circunstâncias temporais probiam descie o princípio a solução grande. A proposta do Ministerio da Justiça ia acabar num processo sunário com uma parte do BGB, uma lei na qual juristas de altíssima qualificaçăo tinham trabalhado por 20 anos. KNUJEL, Roít. Op. cit. p. 2519.

${ }^{2}$ Neste sentido, OTाO, Hansjörg. Op. cit. p. 2. HEß, Burkinat alerta que a praxe quase nâ tinha tempo para estudar e adaptar-se às novas regras o que causou problemas e, com isso, custos imensos. Compare HEß, Burkhart. Die Übergangsregelungen zum Schuldrechtsmodernisierungsgesetz. Deutsches Steuerrecht: Wochenschriff für Steverrecht, Wirtschaftsrecht und Betriebswirtschát. München: C.H. Beck, v. 11, 2002. p. 455. WETZEL, Thomas. Op. cit. p. 117.

43 Uma sinopse das duas versóes do projeto de discussão encontra-se na lurisitenzeitung Tubingen: Mohr Siebeck, $v$. 10 , 2000. p. 524 eseg.

44 No total, eram 150 mudanças sugeridas pelo Bundesrat. Compare Bundesrat-Drucksache 338/01 com decisão(Beschluss) de 13 de julho de 2001. 
contra os votos da oposição, os partidos CDU, CSU e FDP, pelo Bundestag em 11 de outubro de 2001 e pelo Bundesrat em 9 de novembro de 2001. A lei foi publicada no Bundesgesetzblatt (Diário Oficial da União) em 26 de novembro de 2001 e entrou em vigor, como já mencionado, em 1 de janeiro de 2002. Além das mudanças no conteúdo, que serão analisadas a seguir, a reforma trouxe uma alteração técnica importante: todos os parágrafos do BGB receberam títulos oficiais para facilitar o uso da lei ${ }^{45}$. Estes títulos já existiam antes, mas eram inoficiais, quer dizer, não tinham força de lei, e, portanto, não podiam ser invocados como parte da lei. Por exemplo, o título oficial da famosa cláusulageral da boa-fé, § 242 BGB, hoje é "prestaçāo conforme a boa-fé".

Observa-se que a lei de 1 de janeiro de 2002 difere-se de maneira significativa das propostas de 1992 e do projeto de discussão de 2000, mas também da versão consolidada que se tornou projeto de lei $i^{46}$. Na análise seguinte, as diferenças serão explicadas quando for conveniente para o melhor entendimento da lei hoje em vigor.

\section{A. 2 As mudanças na Parte Geral: da perturbação da prestação (Leistungsstörung), sobretudo da impossibilidade do cumprimento, e da prescrição (Verjährung)}

A mudança das normas que regulam a perturbação da prestação foi um dos aspectos mais discutidos da reforma ${ }^{47}$. Não é de se admirar sobre isto, porque o anteprojeto (Diskussionsentwurf) pretendeu harmonizar as perturbaçōes da prestação, abandonando os conceitos do direito adiliciano, que existem há dois mil anos e estavam, até então, presentes no antigo $\mathrm{BGB}^{43}$. A sugestão consistiu em juntar os vários tipos de perturbações em uma só noção, a violação do dever (Pflichtverletzung) ${ }^{49}$, o que teria causado o desaparecimento das regras sobre a impossibilidade, que teve uma posição central no direito das obrigações no BGB de $1900^{50}$. Por isso, parte da doutrina

A. Veja WITZ, Claude. Op. cit. p. 939. Umas denominaçóes foram criticadas por não corresponder à doutrina alemã. Compare KOPPENFELS, Katharina von. Das Widerrústecht be Verłatuchervertägen im BGB - eine Untersuchung des \$ 355 Abs. 1 BGB-RegE. Wertpapiemittellungen: Zeitschrift für Wirtschafts- und Bankrecht. Frankfurt am Main: Herausgebergemeinschaft Wertpapiemitteilungen, v. 29, 2001.p. 1369.

46 OTTO, Hansjörg. Op. cit. p. 3.

47 MATTHEUS, Daniela. Schuldrechtsmodernisierung 2001/2002 - Die Neuordnung des allgemeinen Leistungsstörungsrechts. Juristische Schulung. München: C. H. Beck, v. 3, 2002. p. 209.

48 HONSELL, Heinrich. Einige Bemerkungen zum Diskussionsentwurf eines Schuld rechts moderni sierungs gesetzes. Juristenzeitung. Tübingen: Mohr Siebeck, v. 1, 2001. p. 18

49 Sobre a questão em geral, se a violação de um dever serve para juntar todos estes conceitos, veja SCHAPP, Jan. Empfiehlt sich die "Pflichtverletzung" als Generaltatbestand des Leistungsstörungsrechts? Juristenzeitung. Tübingen: Mohr Siebek, v. 11, 2001. p. 583 e seg.

50 O próprio CANARIS analisa que a categoria da impossibilidade era sobrepesada no antigo $8 G B / 1900$. CANARIS, Claus-Wilhelm. Das allgemeine Leistungsstörungsrecht im Schuldrechtsmodernisierungsgesetz. Zeitschrift für Rechtspolitik. München: C. H. Beck, v. 8, 2001. p. 329. 
criticou o anteprojeto, lembrando que a integração da impossibilidade no conceito da violação do dever deixaria a desejar, porque este conceito tornarse-ía difuso ${ }^{51}$. Exigia-se a conservação da impossibilidade como uma categoria própria do direito das obrigações. O legislador aceitou estas críticas e manteve a impossibilidade que se encontra regulada no $\$ 275 \mathrm{BGB} / 2002^{52}$. Esta norma, hoje em dia, estabelece no seu inciso primeiro:

$\S 275$ 1: Der Anspruch auf Leistung ist ausgeschlossen, soweit diese für den Schuldner oder für jedermann unmöglich ist.

$\S 275$ I: É vedada a pretensão à prestação, se ela for impossível tanto ao devedor quanto a qualquer outra pessoa.

Este inciso junta a impossibilidade subjetiva ("tanto ao devedor") e objetiva ("quanto a qualquer outra pessoa") e ordena as mesmas conseqüências jurídicas (a prestação é vedada) para estes dois tipos de impossibilidade ${ }^{53}$. O BGB/1900 ainda distinguiu entre a impossibilidade subjetiva e objetiva, o que causou problemas ao diferenciar entre estes conceitos; desistindo desta distinção, o novo direito das obrigações pretende simplificar os casos da impossibilidade ${ }^{54}$. É importante lembrar que a pretensão é vedada independentemente de se o devedor causou, de maneira culposa, a impossibilidade ou não ${ }^{55}$.

A diversidade nas conseqüências jurídicas para os diferentes tipos da impossibilidade foi considerada um dos maiores problemas do antigo direito das obrigações. Com o novo $\$ 275$, o legislador conseguiu uma unificaçāo abrangente das conseqüências jurídicas, o que simplifica significativamente a solução dos casos da impossibilidade ${ }^{56}$.

51 Compare TEICHMANN, Anndt. Strukturveränderungen im Recht der Leistungsstörungen nach dem Regierungsentwurf eines Schuldrechtsmodernisierungsgesetzes. Betriebsberater. Heidelberg: Recht und Wirtschaft, v. 30, 2001 . p. 1486. HONSELL, Heinrich, Op. cit, p. 19.

52 Por causa disso, MATTHEUS conclui que a impossibilidade continua tendo sua posiçảo especial ee levada no direito das obrigaçōes. Veja MATTHEUS, Daniela. Op. cit. p.211.

5.3 Exemplos para os dois conceitos: Uma prestação é objetivamente impossivel, se ninguém pode prestar, p. ex., se o objeto da prestação foi destruído: uma árvore cáu no carro já vendido que ainda esteve no terreno do vendedor para o comprador buscálo. A prestaçào é subjetivamente impossivel, se um terceiro, mas nầo o devedor, pode prestar isto acontece, p. ex., se uma outra pessoa que o vendedor é dono da coisa vendida: um ladrăo vende um livro roubado. Como ele năo é dono do livro (a propriedade fica com a pessoa da qual ele roubou o livro), ele não pode cumprir o contrato de compra e venda, transferindo a propriedade para o comprador. Caso o verdadeiro dono do livro nâo queira vendê-lo, o ladrăo, como devedor, năo pode cumprir, comparando o livro do dono verdadeiro. O dono verdadeíro poderia cumprit mas năo tem que nem é obrigado a cumpłir. A prestaçăo do ladrẵo e subjetivamente impossível. Veja TEICHMANN, Andt. Op. cit p. 1486. WIESER, Eberhard. Eine Revolution des Schuldrechts. Neue Juristische Wochenschrift. München: C. H. Beck, v. 2, 2001.p. 122.

55 SCHWAB, Martin. Dasneue Schuldrecht im Überblick. JuristischeSchulung.München:C.H.Beck, v. 1, 2002.p. 2.

s6 Compare MATTHEUS, Daniela. Op. cit. p. 212. ZIMMER, Daniel conclui que a simplicidade do novo sistema faz com que diferenças necessárias já não sejam feitas o que pode díficultar a aplicação das novas normas. ZIMMER, Daniel. Das neue Recht der Leistungsstörungen. Neue Juristische Wodhenschrift. München: C. H. Beck, v. 1, 2002. p. 12. 
Mas novos problemas de interpretação surgiram com os incisos II e II] do parágrafo $275 \mathrm{BGB}$. Neles, trata-se da questão da inexigibilidade (Unzumutbarkeit) da prestação; no inciso ll, estabelece-se que o devedor pode negar a execução da prestação, caso as despesas necessárias para efetuar a prestação sejam inexigíveis ${ }^{57}$. A inexigibilidade pessoal está estabelecida no inciso III, que regula o caso que o devedor tem que prestar pessoalmente, mas a prestação não pode ser exigida por razões pessoais ${ }^{58}$.

O inciso II é baseado na doutrina de CANARIS que traz a idéia da "impossibilidade prática" (pratiksche Unmöglichkeit) ${ }^{59}$. Pensa-se nos casos nos quais a prestação, teoricamente, ainda pode ser efetuada, mas, por causa da mudança de circunstâncias, a prestação traria custos enormes para o devedor, e não se pode esperar que ele preste ${ }^{60}$. $O$ exemplo mais citado e até usado nos considerandos da lei para a modernização do direito das obrigações ${ }^{61}$ é o do anel no fundo do mar. Neste caso, o devedor vendeu um anel, mas, antes de entregar para o comprador, ainda fez um cruzeiro. Durante o cruzeiro, o anel caiu, em alto mar, na água e afundou. Sob estas circunstâncias, a prestação fica, teoricamente, possível, pois o devedor pode contratar especialistas para recolher o anel do fundo do mar, mas os custos para isto excederiam todos os limites da razāo econômica. $O \S 275$ || BGB dá the a possibilidade de livrar-se da obrigação ${ }^{62}$.

Mas há interpretaçōes diferentes desta norma. OTTO, por exemplo, comenta que o caso do anel no fundo do mar enquadrava-se, antes da reforma, sem problemas, no conceito da impossibilidade subjetiva ou, numa presuposição de certa profundidade da água até na categoria da impossibilidade objetiva. Portanto, OTTO aplica, com referência à doutrina antiga, a este caso o inciso l do $\S 275 \mathrm{BGB}^{63}$. Além disso, surgem problemas de distinguir o $\S 275$

57 \$275 II: Der Schuldner kann die Leistung verweigern, 5oweit diese einen Aufwand erfordert, der (...) in einem głobets Missverhältnis zu dem Leistungsinteresse des Gläubigers steht. O inciso 2 foi inserido com reação à discussảo científica sobre a necessidade de tal regra. CANARIS, Claus-Wilhelm. Op. cit.p. 330.

5a \$275 III: Der Schuldner kann die Leistung ferner verweigern, wenn er die Leistung persönich zu erbringen hat und sie ihm (...) nicht zugemutet wercien kann.

59 Oautor também fala de "impossibilidade fática" (áktische Unmöglichkeat). As duas noções são sinónimas. CANARIS, Claus-Withelm. Sondertagung Schuldrechtsmodernisierung: Die Reform des Rechts der Leistungsstörungen. Juristenzeitung. Tubingen: Mohr Siebeck, v. 9, 2001.p. 501.

60 Veja as explicaçöes de SCHLECHTRIEM, Peter. Op. cit. p. 155 , ponto 283.

61 Compare Bundestagsdrucksache $14 / 6040$ de 13 de maio de 2001. p. 129 e seg.

62 Mas isto nảo significa que o devedor nảo seja responsável pelo fato que ele já näo pode prestar. O $\$ 275$ II extingue somente a obrigaçāo a prestar, assim chamada Primärleistungspflicht, mas não atinge as regras sobre a responsabilidade e o5 demais direitos do credor, chamados Sekundärleistungspflichten. Compare o exemplo citado em HUEER, Peter; Faust, Florian. Schuldrechtsmodernisierung: Einführung in das neue Recht. München: C. H. Beck, 2002. p. 13, ponto 16.

63 OTTO, Hansjörg. Op. cit. p. 3. No mesmo sentido FISCHER, Michael. Der Ausschluss der Leistungspticht im Falle der Unmöglichkeit im Entwurf des Schuldrechtsmodernisietungsgesetzes (\$ 275 BCB RegE). Der Betrieb. Dusseldorf: Handelsblatt, v. 36, 2001. p. 1926. 
Il BGB e a quebra da base do negócio, codificado nos $\$ \$ 313$ e seg. $B G B^{64}$. Por tudo isto, o entendimento desta nova norma é considerado difícil ${ }^{65}$ e capaz de gerar problemas na aplicação prática ${ }^{66}$.

Os casos atingidos pelo inciso 11 do $\$ 275$ são denominados "impossibilidade pessoal" (persönliche Unmöglichkeit). Por meio desta figura jurídica, solucionam-se os problemas que surgem quando a prestação tem que ser efetuada pessoalmente pelo devedor, mas, sob as circunstâncias concretas, tal prestação não pode ser exigida ${ }^{67}$. Um exemplo é uma cantora, cujo filho adoeceu com perigo de morte. Se ela foi contratada para apresentar-se, nada The impede, objetivamente, de cantar uma música alegre no palco, porém, do ponto de vista pessoal, isto é totalmente inexigível ${ }^{68}$. Esta norma quebra parcialmente a doutrina de CANARIS, que serviu como base para a elaboração do $\S 275 \mathrm{BGB}$, pois, na sua visão, a impossibilidade pessoal pode ser solucionada, aplicando a cláusula-geral da boa-fé objetiva, $\$ 242 \mathrm{BGB}^{69}$. A positivação no $\$ 275$ III BGB faz com que esta figura influencie a interpretação do $\S 275 \|$ BGB, o que abre um novo campo para conceitos diferentes ${ }^{70}$.

Para questões processuais, é importante distinguir entre o inciso l e os incisos II e III do $\$ 275$ BGB. A formulação do inciso I, que estabelece que a prestação é vedada (die Leistung ist ausgeschlossen) ${ }^{71}$, cria um assim chamado "Einwand", um reparo. O reparo tem que ser considerado de ofício, quer dizer, o juiz vai aplicar o $\$ 275$ I BGB sem que uma parte precise invocá-lo. Os incisos II e III do $\$ 275$ BGB dão uma "Einrede" para o devedor, determinando

64 Sobre este problema, compare FISCHER, Michael. Op. cit. p. 1923.

65 Veja SCHWAB, Dieter. Op. cit. p. 2. No mesmo sentido STOLL, Hans. Notizen zur Neuordnung des Rechts der Leistungsstörungen. Juristenzeitung. Tübingen: Mohr Siebek, v. 11, 2001 . p. 591.

SCHLECHTRIEM, Peter. Schuldrecht: Algemeiner Tejl. 5, ed. Tübingen: Mohr Siebek, 2003, p. 151, ponto 276.

67 KROPHOLLER, Jan. Bürgerliches Gesetzbuch: Studienkommentar. 7. ed. München: C. H. Beck, 2004.p. 151, ponto 5.

68 Exemplo usado pelos motivos. Bundestagsdrucksache 14/6040 de 13 de maio de 2001, p. 130. Comentado e explicado por SCHWAB, Dieter. Op. cit. p. 2.

69 CANARIS, Claus-Wilheim. Op. cit. p. 501. Para a aplicaçăo das regras sobre a quebra positiva da base do negócio ZIMMER, Daniel. Op. cit. p. 4.

70 Uma outra visão do conceito da impossibilidade, com base no $\$ 275$ ll BCB, traz OTTO, Hansjörg. Op. cit, p. 3 e seg.

71 A impossibilidade na figura do reparo foi instalada somente no fim do processo legislativo. Compare SCHEECHTRIEM, Peter. Op. cit. p. 153, ponto 282. 
que a prestação pode ser negada (kann die Leistung verweigern). Para que estas normas tenham efeito no processo, o devedor tem que invocá-las ${ }^{72}$.

Um novo paradigma para a teoria dos contratos no âmbito da impossibilidade foi introduzido pelo novo $\$ 311$ a $/ \mathrm{BGB}^{73}$. Esta norma trata do contrato, cuja execução já é objetivamente impossível antes da celebração (objetive anfängliche Unmöglichkeit), p. ex., quando as partes, ao celebrar o contrato, não sabiam que o objeto da prestação foi destruído. $O$ antigo $B G B$ ordenava, neste caso, a nulidade do contrato, $\$ 306 \mathrm{BGB} / 1900^{74}$; para estabelecer a responsabilidade contratual das partes, usou-se a figura da garantia, isto é, a idéia de que a parte que se obriga a prestar um certo objeto garante, dentro de determinados limites, a existência de tal objeto. O novo $\S 311$ a 1 inverte este paradigma, colocando que um contrato, cuja execução já é objetivamente impossível antes da celebração, é plenamente válido ${ }^{75}$. Mas isto não significa que o credor mantenha sua pretensão à prestação primária (Primärleistung). Muito pelo contrário, o conteúdo do contrato limita-se às pretensões secundárias ${ }^{76}$. Com esta visão, o direito alemão segue os padrões internacionais, como, p. ex. os Princípios do UNIDROIT ou o CISG, que também prevêem a validade do contrato, caso a prestação seja objetivamente impossivel antes da celebração do mesmo ${ }^{77}$.

A impossibilidade da prestação gera direitos à prestação secundária (Sekundärleistungsrechte), entre eles o mais importante: a indenização por danos (Schadensersatz). Como se lê no $§ 283$ BGB, o credor pode exigir indenização nos pressupostos do $\$ 280$ BGB. já fol mencionado que o legislador pretendia instalar uma única base legal para todos os tipos da perturbação de deveres. Esta norma é o atual $\S 280 \mid \mathrm{BGB}$, que pode ser visto como o coração

72 Como comenta KNÜTEl, isto gera um estado de incerteza porque o credor não pode saber se o devedor invocará os § $275 \mathrm{I}$ ou ll $\mathrm{BGB}$ ou não. $\mathrm{O}$ autor é de opiniăo que isto traz nos tempos modernos, nos quais o fator da velocidade é de alla importância no comércio, inseguranças perigosas. KNÜTEL, Rolf. Op. cit. p. 2520 . A norma é defendida por TEICHMANN, Andt. Op, cit. p. 1487. CANARIS, Claus-Wilhelm também critica a construçăo do $\$ 27511$ com base numa "Einrede". Veja a manifestaçăo de CANARIS na discussäo da "Sondertagung Schuldrechtsmodemisieurng" (congresso extraordinário: modernização do direito das obrigações) no relatório de ŁANGENBUCHER, Katja. Diskussionsbericht zum Vortrag von Claus-Withelm Canaris. Juristenzeitung. Tübingen: Mohr Siebek, v, 10, 200t. p. 528.

73 Comapre HUBER, Peter; FAUST, Florian. Op. cit. p. 17, ponto 28.

74 Veja KROPHOLLER, lan. Op. cit. p. 194, ponto 2.

t゙: ZIMMER, Daniel. Op. cit.p. 3.

76 Uma análise profunda deste novo paradigma faz MATTHEUS, Daniela. Op. cit. p. 214. O novo conceito foi criticado por KNÜJEL, porque surgem problemas de integrar uma obrigaçăo que näo cria uma pretensão primária no âmbito das pretensões secundárias. Veja KNÜTEL, Rolt́, Op. cit. p. 2520. \$TOLL alenta que $\$ 311$ a) seja escusado, pois os $\$ \$ 281$,

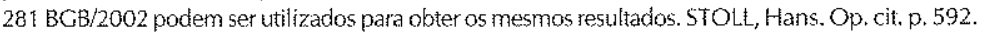

$\eta 7$ GRUNEWALD, Barbara. Vorschläge für eine Neuregelung der anfänglichen Unmöglichkeit und des anfänglichen Unvermögens, Juristenzeitung, Tubingen: Mohr Siebek, v. 9, 2001, p. 433 e seg. 
do novo direito das perturbações de deveres ${ }^{78}$. A pretensão à indenização sempre deve basear-se neste parágrafo, eventualmente em conjunto com outras normas ${ }^{79}$. Uma análise do direito à indenização tem que partir, portanto, do $\S 280 \mathrm{BGB}^{80}$.

Quatro elementos geram a responsabilidade por violação de dever ${ }^{81}$ : (1) a relação obrigacional, isto é, sem tal relação (Schuldverhältnis) válida, não há direito à indenização. Neste ponto, enquadram-se famosos problemas, tais como a culpa in contrahendo e a culpa post contratum finitum.

A título de exemplo, explica-se a culpa in contrahendo, sua problemática e a solução oferecida pelo novo $\mathrm{BGB}^{82}$. Quando uma parte infere direitos da outra antes da celebração do contrato, ainda não há ${ }^{83}$, no momento do infringimento, uma relação contratual entre as partes, o que não permitiria, no fundo, indenizações com base no direito contratual, mas a parte infringida somente é protegida pelo direito dos delitos. Para evitar este resultado e estabelecer uma responsabilidade obrigacional, a jurisprudência desenvolveu a culpa in contrahendo. Por meio desta figura, criou-se uma relação "quasecontratual" para poder abranger danos pré-contratuais ${ }^{84}$; o legislador de 2002 codificou esta instituição, que já tinha se tornado costume no direito alemão. O novo $\$ 311$ II estabelece que uma relação obrigacional também surge por início de negociações, preparação de um contrato ou contatos comerciais parecidos ${ }^{85}$.

Além de uma relação obrigacional, exige-se (2) uma violação de deveres, distinguindo deveres relacionados à prestação (leistungsbezogene Pflichten) dos não relacionados à prestaçāo (nicht-leistungsbezogene Pflichten). Esta distinção fica muito clara no novo $\$ 241$, intitulado "deveres oriundos da relação obrigacional" (Pflichten aus dem Schuldverhältnis). O inciso I determina os deveres relacionados à prestação, colocando que o credor pode exigir do

78 Compae LORENZ, Stephan. RIEM, Thomas. Op. cit.p.90, ponto 169. SCHMID T-RÄNISCH, Jürgen. Das neue Schułdrecht: Anwendung und Auswirkungen in der Praxis. Köln: Heymanns, 2002. p. 111, ponto 316.

79 SCHWAB, Dieter. Op. cit. p. 3. MATTHEUS, Daniela. Op. cit. p. 210.

so Trata-se de uma matéria de alta complexidade. Uma primeita orientação com gráficas muto úteis foi elaboraxla por LORENZ, Stephan, Leistungsstörungen: Arbeitshilfe zum neuen Schuldrecht. Anwalt-Das Magaxin. Hannover: Heise, v. 12, 2001.p. 12 eseg.

\$1 Compare as explicações de MEDICUS, Dieter. Op. cit. p. 200, ponto 417 e seg.

32 Aprovando o conteúdo da codificaçăo da culpa in contrahendo, mas exigindo uma outra colocaça na lei, SCHAPP, Jan. Op. cit. p. 588 e seg. Contra a codificaçäo WETZFt, Thomas. Op. cit. p. 125.

83. E talvez nunca haja uma rełaçào contratual, porqúu as partes ainda estăo negociando.

84 Existe uma doutrina vasta sobre a culpa in contrahendo no antigo BGB. Sobretudo a justificativa para esta figura e a sua integração nas demais pretensōes ả indenização foram discutidas.

85 \$311 1I BCB: Ein Schuldverhältnis (...) entsteht auch durch 1. die Aufnahmevon Vertragsvernandlungen, 2. die Anbahnung anes Vertrags (...), oder 3. ähnliche geschäftiche Kontakte. Veja HUBER, Peter; FAUST, Florian. Op. cit. p. 69, ponto 9. SCHMIDT-RÄNTSCH, Jürgen. Op. cit. p. 143, porto 421 . 
devedor uma prestação ${ }^{86}$, o que estabelece deveres de possibilitar, em todos os sentidos, o cumprimento da obrigação. O inciso Il cria deveres de respeitar os direitos, bens jurídicos e interesses da outra parte ${ }^{87}$, referindo-se a deveres que estão fora da relação obrigacional. No direito antigo, estes deveres foram criados por meio da figura do infringimento positivo do contrato (positive Vertragsverletzung) ou, no âmbito pré-contratual, por meio da culpa in contrahendo. Um exemplo clássico de infringimento de deveres não relacionados à prestação é o de um pintor que, ao pintar as paredes de um quarto, danifica os móveis no quarto ${ }^{8 B}$. Neste caso, o cumprimento do dever principal, isto é, pintar as paredes, foi cumprido perfeitamente; mas o devedor não tomou cuidado de proteger os bens jurídicos do credor, danificando seus móveis. Portanto, surge a responsabilidade por violar um dever não relacionado à prestação.

O terceiro pressuposto para aplicação do $\$ 280$ lé (3) um dano causado pela violação e, como último ponto (4), a culpa (Verschulden) ${ }^{89}$, estabelecida no $\$ 280$ inciso I frase 2 . O legislador alemão ficou fiel ao princípio de que não há responsabilidade sem culpa e decidiu não seguir o exemplo da Convenção de Viena sobre a compra e venda internacional de mercadorias que conhece responsabilidade sem culpa ${ }^{90}$. A noção de culpa foi determinada no $\S 276$, colocando que o devedor responde por dolo e negligência, caso uma responsabilidade mais forte ou mais fraca não tenha sido prevista no contrato, p. ex., por uma garantia. A expressão condicional (caso uma responsabilidade...) não se encontrava no antigo $B G B$ e foi inserida para sublinhar a importância central do acordo entre as partes ${ }^{91}$.

Com esta explicação do $\$ 280$, é possível entender todo o sistema de indenização do novo BGB. O legislador colocou o $\$ 280$ como base e complementou a norma com outras regras em casos especiais. Logo a seguir, nos $\$ \$ 281-283$, encontram-se modificações da regra básica, § 280. Por exemplo, o $\$ 281$ regula, entre outros, a indenização pela não-efetuação da prestação (Schadensersatz wegen nicht erbrachter Leistung), estabelecendo que o credor somente pode exigir indenização, se ele colocou um prazo para o devedor efetuar a prestação. Isto é somente uma de várias situações que podem gerar uma pretensão à indenização de uma das partes contratuais. Na sua análise das estruturas básicas do novo direito da perturbação da prestação, OTTO desenvolveu uma tabela que serve muito bem para entender as interdependências das normas ao redor do $\$ 280^{92}$.

\footnotetext{
sif $\$ 241$ I: (..) ist der Gläubiger berechtigt, von dem Schuldner eine Leistung zu fordern.

${ }^{\beta} \$ 241$ If: (...) zur Rücksicht auf die Rechte, Rechtsgüter und Interessen des anderen Teils verpflichten.

8: Compare MATTHEUS, Daniela. Op. cit.p. 211.

s9

Critico quanto ao uso desta palavra SCHLECHTRIEM, Peter. Op. cit. p. 168 ponto 321.0 autor comenta que existe responsabilidade sem culpa nos casos nos quais o devedor deu uma garantia. RANIERI, Filippo. Op. cit. p. 949. KROPHOLLER, Op. cit. p. 152, ponto 1.

SCHWAB, Dieter, Op. cit. p. 3. SCHMIDT-RÄNTSCH, Jügen. Op. cit. p. 149, ponto 438 eseg.

9? OTTO, thansjörg. Op. cit. p. 4.
} 
Mudanças foram feitas no direito de arrependimento (Rücktrittsrecht), que está regulado no $\S 323$, mas o conceito básico não foi atingido: na visão alemã, o arrependimento permite-se somente em contratos bilaterais e depois de dar uma segunda chance ao devedor para cumprir. Esta segunda chance é chamada de "Nachfrist" e definida como sendo uma declaração de vontade unilateral; com este conceito, o direito alemão segue o art. 49 da Convenção de Viena sobre a compra e venda internacional de mercadorias ${ }^{93}$. Somente em casos determinados, a colocação de uma Nachfrist é prescindível. É notável que os pressupostos para exercer o direito ao arrependimento assemelham-se muito aos do $\$ 281$, que trata da indenização; esta adaptação deu-se pelo fato de que a pretensão à indenização jă não exclui o direito de arrependimento ${ }^{94}$.

O novo direito de arrependimento aplica-se a todos os tipos de relações obrigacionais, incluindo os oriundos de le $i^{95}$. O antigo sistema foi criado somente para o direito de arrependimento combinado entre as partes num contrato, mas não para os garantidos pela lei. Portanto, aplicavam-se as normas sobre o direito contratual de arrependimento de maneira análoga ao direito de arrependimento constatado na lei. O BGB/2002 abrange todos os tipos de direito de arrependimento e acaba, desta maneira, com vários problemas de delimitação $0^{96}$.

Sob o regime do antigo $B G B / 1900$, o credor tinha que decidir se pediria indenização ou desejaria realizar seu direito de arrependimento $(\$ \S 325$ inciso I frase 1, 326 incisol frase $2 \mathrm{BGB} / 1900$ ), o que fez com que a jurisprudência buscasse caminhos para ajudar o credor que tinha se decidido precipitadamente pelo direito de arrependimento ${ }^{97}$, pois, uma vez exercido este, o credor já não teria a possibilidade de exigir indenização com base no direito obrigacional. Com o novo sistema, este problema não existe mais, rompendo com o princípio de diferenciar os diferentes tipos de perturbação da prestação, para levar em consideração os costumes jurisprudenciais ${ }^{98}$.

A prescriçāo, regulada nos $\S \S 194$ e seguintes, foi um outro ponto central na discussão sobre a reforma ${ }^{99}$. Vários problemas e desigualdades por causa de prazos de prescrição diferentes (os prazos diferiam entre seis semanas e trinta anos), no antigo $\mathrm{BGB} / 1900$, indicaram uma harmonização ${ }^{10 \%}$. Portanto,

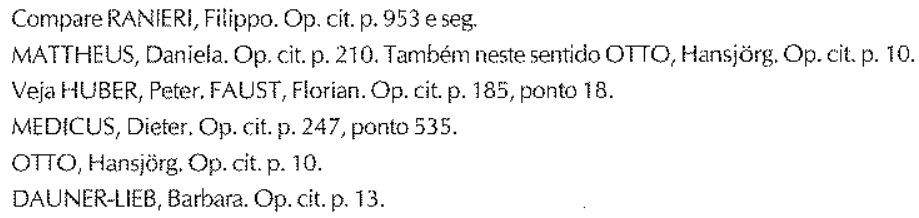
geplanten Schuldrecintsmodemisierungsgesetz. Juristenzeitung. Tubingen: Mohr Siebek, v. 6, 2001. p. 283.

LORENZ, Stephan; RIEHM, Thomas. Op. cit. p. 19 ponto 32. Mais detalhado HEINRICHS, Helmut. Entwurf eines Schuldrechtsmodernisierungsgesetzes: Neuregelung des Verjährungsrechts. Betriebsberater. Heidelberg: Recht und Wirtschaft, v. 28, 2001. p. 1417. 
o prazo da prescrição regular foi diminuído de 30 anos do $B G B / 1900$ a três anos, $\S 195 \mathrm{BGB} / 2002^{101}$. Esta mudança radical significa, como coloca HONSELL, "cair de um extremo para o outro"102. Para chegar a uma solução diferenciada, o legislador previu prazos diferentes para certos tipos de pretensōes e estabeleceu nos $\S \S 196$ e 197 BGB/2002 o seguinte: pretensōes que têm como conteúdo a transferência da propriedade de um terreno ou de outros direitos sobre um terreno prescrevem em dez anos. $O$ antigo prazo de trinta anos foi mantido para pretensōes tituladas (titulierte Ansprüche), para pretensōes do direito de família ${ }^{103}$ e do direito das sucessōes e para direitos reais (dingliche Rechte).

A reforma do prazo da prescrição se deu pelo fato de que a grande majoria na doutrina e na praxis considerou trinta anos muito tempo; já na elaboração do BGB de 1900, a questão de uma prescriçāo mais curta foi discutida, mas as comissões acabaram votando pelo prazo longo de trinta anos, oriundo do direito romano. O que já era duvidoso no fim do Século XIX, tornou-se inaceitável no Século XXI, marcados pela velocidade e por perspectivas mais curtas. Até os críticos das novas regras da prescrição concordam que um prazo de trinta anos, hoje em dia, não é conveniente ${ }^{104}$.

Não somente o prazo da prescrição foi reduzido, mas o legislador mudou, de maneira mais abrangente, o conceito da prescrição contratual, o que pode ser visto numa análise das normas sobre o início da prescrição. Sob o regime do BGB de 1900, o prazo da prescrição começou a correr com o surgimento da pretensão; isto significa que o prazo iniciou, normalmente, com o vencimento da pretensão que está sujeita à prescrição. Como a prescrição não foi vinculada ao conhecimento das partes da pretensão, este antigo conceito da prescrição contratual é chamado de "sistema objetivo" (objetives System) ${ }^{105}$.

O novo conceito muda para o "sistema subjetivo" (subjektives System) ${ }^{106}$ e estabelece, no $\$ 199 \mathrm{BGB} / 2002$, que o prazo da prescrição regular inicia no fim do ano no qual o credor ficou sabendo da pretensão ou não ficou sabendo

w1 MEDICUS, Dieter. Gesetzliche Schuldverhältnisse. 4. ed. München: C. H. Beck, 2003. p. 5. ERNST, Woligang alerta que esta mudança afeta, sobretudo, pessoas que näo celebram com certa freqüuencia determinados contratos. fnstituiçōes profissionais, como p. ex. bancos, nāo teriam muitos problemas de adaptar-se ao novo prazo curto. ERNST, Wolfgang. Schuldrechtsreform 2001/2002: Zum Diskussionsentwurf des chuldrechtsmodernisierungsgesetzes. Zeitschrift für Rechtspolitik. München: C. H. Beck, v. 1, 2001, p. 5.

302 HONSELL, Heinrich. Op. cit. p. 20.0 autor recomenda um prazo de 10 anos para prescriçăo regular.

303 Uma análise profunda sobre os efeitos da reforma da prescriçăo dă BÜTTNER, Helmut. Schuldrechtsmodernisierung und Familienrecht, insbesondere Verjährung, Verwirkung und Verzug. Zeitschrift für das gesamte Familienrecht. Düsseldort: Handelsblatt, v. 6, 2002, p. 361 eseg.

104 VejaHONSELL, Heinrich. Op. cit. p. 19.

105 SCHWAB, Dieter. Op. cit. p. 1.

506 Outros falam de "pressuposto subjetivo" (subjetive Voraussetzung). Veja HEINRICHS, Helmut. Op. cit. p. 1417. 
por negligência grave (grobe Fahrlässigkeit) ${ }^{107}$; o fato de o início ser somente no fim do ano recebe o nome de "Ultimo-Verjährung"108. Desta maneira, limitam-se os efeitos fortes que um prazo de prescrição curto (três anos) traz para o credor; por outro lado, o sistema subjetivo precisa de uma limitação objetiva para que o credor não possa alegar seu desconhecimento da pretensão anos mais tarde ${ }^{109}$. Portanto, o $\$ 199 \mathrm{BGB} / 2002$ estabelece no seu inciso IV que a pretensão prescreve dez anos depois do seu vencimento, independentemente do conhecimento do credor ${ }^{110}$.

O sistema subjetivo da prescrição não é totalmente novo para o direito alemão. O BGB de 1900 já usou-a no direito dos delitos ( $\$ 825 \mathrm{BGB} / 1900$ ). Mas, com a reforma do direito das obrigaçōes, o sistema tornoumse princípio geral (allgemeines Prinzip) do BGB alemão ${ }^{1 i}$.

Fora deste novo sistema fica a prescrição de pretensões à indenização por lesão da vida, do corpo, da saúde ou da liberdade, $\S 199$ inciso 2. Para proteger bem os direitos humanos, a lei estabelece que estas pretensōes prescrevem em trinta anos com base no sistema objetivo, quer dizer, independentemente do conhecimento do credor. Vale notar que o texto não fala em "lesão de direitos humanos" mas enumera os bens jurídicos protegidos e obtém, desta maneira, mais clareza. Pois a mesma enumeração de bens jurídicos encontra-se na norma central do direito dos delitos, $\$ 823$ inciso I BGB. A jurisprudência e doutrina sobre esta norma, portanto, podem ser usadas para interpretar o $\$ 199$ inciso 2.

\section{B. 1 As novidades na Parte Especial, sobretudo no contrato de compra e venda}

As mudanças mais sencíveis na Parte Especial do BGB foram aplicadas

ao contrato de compra e venda, devido à obrigação da transposição das Diretivas. Além disso, queria-se simplificar e estruturar melhor os $\$ 433 \mathrm{e}$ seg. $B G B$, que contêm as normas sobre o contrato de compra e venda. Exceções e tratamentos diferentes para situações semelhantes ou iguais deveriam ser evitados. Encontraram-se, p. ex., no BGB/1900, normas especiais, tratando de assuntos como o contrato parecido com o contrato de compra e venda (kaufähnliche Verträge, $\$ 445 \mathrm{BGB} / 1900$ ), o contrato de compra e venda de coisa incerta (Gattungskauf, $\S \S 480$ e 493 BGB/1900) e o contrato de compra

39) Em favor a esta subjetivaçăo ERNST, Wolfgang. Op. cit. p. 8. EIDENMÜLLER, Horst. Op. cit. p. 285.

:0a BÜTTNER, Helmut. Op. cit. p. 362.

109 Compare HONSELL, Heinrich. Op. cit. p. 20.

:10 LORENZ, Stephan; RIEHM, Thomas. Op. cit. p. 32, ponto 57.

11: SCHWAB, Dieter, Op. cit. p. 2. 
e venda de gado (Viehkauf, $\S \S 481$ e seg.). Todas estas exceções foram tiradas da lei, estabelecendo conceitos gerais e harmonizados ${ }^{112}$.

Como norma central do contrato de compra e venda ficou o $\$ 433$, que estabelece os deveres das partes. Na primeira frase do seu inciso l, está que o vendedor é obrigado a entregar a coisa de débito ao comprador e torná-lo dono da coisa ${ }^{113}$. Esta idéia básica do contrato de compra e venda não foi alterada pelo legislador. A grande novidade, entretanto, encontra-se na segunda frase do inciso I do $\$ 433$ BGB/2002, que obriga o vendedor a fornecer a coisa sem vício de coisa (Sachmangel) nem vício de direito (Rechtsmangel) ${ }^{114}$. O BGB antigo não era claro quanto à questão de se o fornecimento de uma coisa viciada cumpre o contrato ou näo. Somente o vício de direito era regulado expressis verbis no $\S 434 \mathrm{BGB} / 1900$, no qual se estabeleceu que não era possível cumprir a obrigação com uma coisa acometida de tal vício. A doutrina discutia, com base nesta norma, se o vício da coisa deveria ser tratado como o vício de direito ou se seria melhor distinguir os dois. Dependendo do ponto de vista, permitia-se o cumprimento do contrato de compra e venda com o fornecimento de uma coisa viciada ou não, o que significava limitar o credor aos seus direitos secundários (caso considerasse-se o fornecimento viciado um cumprimento) ou mantendo o direito primário oriundo do $\$ 433$ I. Com o novo BGB/2002, esta discussão foi abstraída ${ }^{115}$, pois o legislador deixou claro que o fornecimento de uma coisa viciada, independentemente de tratar-se ou não de vício da coisa ou vício de direito, não efetua o cumprimento do contrato, o que tem como conseqüência que o credor mantém seu direito primário do $\$ 433 !^{116}$.

Uma definição da noção de vício encontra-se no novo § 434 BGB/2002; esta norma de apoio (Hilfsnorm) foi elaborada com base no artigo 2. da Diretiva sobre compra de bens de consumo ${ }^{117}$ e segue o conceito subjetivo do erro. $\mathrm{O}$ inciso I determina que a coisa tem que ter a qualidade combinada entre as partes (vereinbarte Beschaffenheit); se nāo há acordo entre as partes sobre a qualidade, a coisa tem que encontrar-se em um estado no qual ela pode ser usada para os fins pressupostos no contrato (vertraglich vorausgesetze Vewendung) ou, se não for possível determinar os fins pressupostos no contrato,

\footnotetext{
132 Compare BÜDENBENDER, Ultich. Op. cit. p. 314. O autor elabora, numa análise sistenática, o campo de aplicação das regras sobre o contrato de compra venda no novo BGB de 2002.

$1: 3 \$ 433 \mathrm{l}$ (...) dem Käufer die Sache zü̈bergeben und das Eigentum an der Sache zu verschaffen. Fundamental para o contrato de compra e venda no direjto alemáo GURSKY, Karl-Heinz. Schuldrecht: Besonderer Teil, 4. ed. Heidelberg: C. F. Müller, 2002, p. 7eseg.

11. Compare WIESER, Eberhard. Op. cit. p. 123.

115 GSELL, Beate. Kaufrechtsrichtinie und Schuldrechtsmodernisierung. Juristenzeitung. Tübingen: Mohr Siebek, v. 2 , 2007. p. 65. HELDRICH, Andreas. Op. cit. p. 2523

:16 Sobre o assunto, compare a análise de HAAS, Lothar; MEDICUS, Dieter; ROLLAND, Walter; SCHÄFER, Carsten; e WENDTIAND, Holger. Das neue Schuidrecht. München: C. H. Beck, 2002, p. 13

is DAUNER-LIEB, Barbara. Op. cit. p. 13.
} 
para os fins usuais (gewöhnliche Verwendung - compare inciso II do $\$ 434$ $\mathrm{BGB} / 2002)^{118}$. Este método de determinar o vício referemse à pergunta "como o quê e para quê" (als was und wofür) a coisa foi adquirida; a resposta pode ser encontrada na denominação da coisa adquirida ou no preço ${ }^{119}$.

O direito comunitário trouxe novas dimensões para a noção de vício da coisa. Os fins usuais são interpretados conforme às manifestaçōes públicas (öffentliche Äußerungen) do vendedor ou do produtor sobre a coisa vendida ${ }^{120}$. O vendedor ou produtor não precisa manifestar-se pessoalmente. É suficiente que um ajudante (Gehilfe) tenha feito as declarações. O vendedor somente fica livre da obrigação de fornecer um bem que corresponde às manifestaçōes públicas, caso ele não soubesse destas manifestações nem pudesse saber ${ }^{121}$. Ainda vale lembrar que somente manifestações concretas sobre o produto têm como conseqüência a aplicação do $\S 434$ inciso I frase 3 , ao passo que ditos gerais não sejam suficientes ${ }^{122}$.

A transposição do artigo 2 , inciso $V$ da Diretiva sobre compra de bens de consumo, o $\$ 434$, inciso II, traz uma nova regra, chamada "cláusula de montagem" ou "cláusula IKEA"123. Trata-se de dois casos: primeiramente, o vendedor monta a coisa de maneira errada; ou, em segundo lugar, ele fornece uma instrução de montagem que induz o comprador a montar a coisa de maneira errada ${ }^{124}$. Estes problemas foram solucionados, sob o regime do antigo BGB de 1900 , por meio dos deveres secundários ${ }^{125}$. O vício é automaticamente sanado quando a montagem é atingida ${ }^{126}$. É importante lembrar que $\$ 434$ inciso II refere-se somente a contratos de compra e venda. Se, no contrato concreto, a montagem é o seu ponto principal, trata-se de um contrato de empreitada, não de um contrato de compra e venda, e outras regras são aplicadas ${ }^{127}$.

118 SCHELLHAMMER, Kurt. Die Haftung des Verkäufers für Sach-und Rechtsmängel - Neue Struktur und neuer Mangelbegriff. Monatsschrift für Deutsches Recht. Köln: Dr. Otto Schmidt, v. 5, 2002. p. 243.

119 SCHELLHAMMER, Kurt. Op. cit. p. 244. Faz uma diferença se um carro foi vendido como "carro novo" "carro usado" OU ${ }_{n}$ carro acidentado".

120 PRE Iß, Bernd. Des einen Freud, des anderen Leid: Neue Rechtslage für Käufer und Verkäufer. Magazin für Computer und Technik. Hannover: Heise, v. 4, 2002.p. 182

121 BRÜGGEMEVINCULAÇÃO PRÓPRIA SEM CONTRATO; A PUBLICIDADE EOS NEGÓCIOS PRELIMINARES NO CODIGO CIVIL2002 ENO CODDIGODE DEFESA DO CONSUMIDOR.

12\% SCHELLHAMMER, Kurt. Op. cit. p. 244 e seg. No mesmo sentido LORENZ, Stephan; RIEHM, Thomas. Op. cit. p. 259, ponto 487 .

123 DAUNER H.JEB, Barbara. Op. cit. p. 13. "KEA" é uma das maiores lojas de móveis na Alemanha, comparável às Casas Baia no Brasi?. Existe a fama de que as instruçōes de montagem dos seus produtos são dificeis de entender. Veja também GSEL.L, Beate. Op. cit. p. 66

124 GURSKY, Karl-Heinz comenta que o comprador nem precisa montar a coisa, se ele nota a inutilidade da instrução antes e, por isto, näo tenta montar a coisa. GURSKY, Karl-Heinz. Op. cit. p. 11.

125 DAUNER-LIEB, Barbara. Op. cit.p. 13.

126 HAAS, Lothar; MEDICUS, Dieter; ROLLAND, Walter; SCHÄFE, Carsten; e WENDTLAND, Holger. Op. cit. p. 14-15.

127 SCHELLHAMMER, Kurt. Op. cit. p. 245. 
Por úlimo, o $\$ 434$ inciso lll estabelece que o fornecimento de uma coisa errada (Falschlieferung), também chamada de fornecimento de um aliud, e o fornecimento insuficiente (Zuweniglieferung) são equiparados a um vício ${ }^{128}$. Com isto, tornam-se obsoletos problemas de delimitação entre o fornecimento de uma coisa viciada e de um aliud ${ }^{129}$; a jurisprudência enfrentava, sob o regime do $\mathrm{BGB} / 1900$, o problema de delimitar, se uma coisa ainda era objeto da obrigação, só que viciada, ou se tratava-se de uma outra coisa; estes problemas se deram, sobretudo, nos contratos de compra e venda de coisa incerta.

As conseqüências jurídicas de um vício encontram-se nos $\S \S 437$ e seg. e são uniformizadas para todos os tipos de vícios. Primeiramente, o comprador tem direito a um adimplemento tardio (Nacherfüllung), $\$ \$ 437$ n. 1 e 439 . A lei reconhece duas maneiras deste adimplemento tardio, das quais uma é o fornecimento de uma nova coisa sem vício (Nachlieferung) e a outra, o conserto da coisa viciada (Nachbesserung). O comprador pode escolher se ele prefere o fornecimento de uma coisa sem vício ou o conserto da coisa fornecida, $\S 439$, inciso I, mas o vendedor pode recusar a escolha do comprador se ela gera custos desproporcionais ${ }^{130}$.

Somente se o adimplemento tardio fracassa, o comprador tem três outros direitos obrigacionais estabelecidos pelo $\S 437 \mathrm{BGB} / 2002$ : a rescisão do contrato (Rücktritt), o abatimento do preço (Minderung) e o direito à indenizaçāo (Schadensersatz) ${ }^{131}$. Esta exigência do fracasso do adimplemento tardio não consta na lei, muito pelo contrário, o $\$ 437$ induz o entendimento que os quatro direitos enumerados estão livremente à disposição do comprador. Somente quando se leva em consideração que esta norma se refere à parte geral do direito das obrigações e que nesta a rescisão do contrato, o abatimento do preço e a indenização exigem a colocação de um prazo para um adimplemento tardio, fica claro que a tentativa de um adimplemento tardio é indispensável para abrir o caminho para os outros três direitos ${ }^{132}$. Portanto, não somente o comprador tem o direito de exigir tal adimplemento tardio, mas o vendedor também tem direito a uma "segunda chance" de fornecer antes que o comprador possa exercer todos os outros direitos contratuais ${ }^{133}$.

\footnotetext{
${ }^{328}$ HUBER, Peter. FAUST, Florian. Op. cit. p. 308, ponto 59 e seg.

329 A diferença mantém sua importância somente nas questöes da prescrição. Veja LORENZ, Stephan; RIEHM, Thomas. Op. cit. p. 262, ponto 490 e seg.

130 SCHWAB, Dieter. Op. cit. p. 5.

13: LORENZ, Stephan. RIEHM, Thomas. Op. cit. p. 270 , ponto 504.

132 Compare KROPHOLLER, Jan. Op. cit. p. 297, ponto 1. Este sistema foi exigido pela Diretiva solore a Compra e Venda de Bens de Consumo, como relata GSELL, Beate. Op. cit. p. 67.

133 Para uma análise detalhada, veja BÜDENBENDER, Ulirich. Op. cit. p. 315. Também BITTER, Georg; MEIDT, Eva. Nacherfüllungsrecht und Nacherfüllungspflicht des Verkäufers im neuen Schuldrecht. Zeitschrift fur Wirtschaftsrecht. Köln: RWS, v. 48, 2001.p. 2116.
} 
Por causa da sua primazia, o adimplemento tardio tornou-se o direito secundário mais importante no novo direito das obrigações ${ }^{134}$.

No novo $\mathrm{BGB} / 2002$, o caráter dos direitos à rescisão e à mudança do preço foi mudado. Conforme o Codex de 1900, estas duas figuras davam o direito ao comprador de obrigar o vendedor a solucionar ou mudar o contrato. Isto trazia problemas processuais, porque o comprador, caso quisesse exercer o direito à rescisão ou mudar o preço, tinha que entrar com uma ação para obrigar o vendedor a consentir com mudança ou com solução do contrato. Num segundo passo, foi necessário entrar com mais uma ação para exigir a execução do contrato mudado ou solucionado. Embora a jurisprudência tenha permitido, por construções jurídicas difíceis, juntar as duas açōes numa só e realizar os direitos oriundos do contrato, o novo direito das obrigaçōes evita tais construções, dando ao comprador um direito unilateral (Gestaltungsrecht) para o exercício dos direitos aqui em questão, $\S \S 349,441$, inciso 1 , frase $1^{135}$.

O direito do consumidor ganhou um espaço próprio nas regras sobre o contrato de compra e venda. O subtítulo III da parte especial do direito das obrigaçōes ( $\$ \S 474-479$ ) traz regras sobre a compra e venda de bens de consumo (Verbrauchsgüterkauf). A definição deste termo está no $\$ 474$, inciso I, que estabelece a compra e venda de bens de consumo nos seguintes termos: um consumidor compra um bem móvel de um fornecedor ${ }^{136}$. Vale notar que esta definição abrange todos os tipos de contratos de compra e venda celebrados entre um consumidor e um fornecedor, incluindo os contratos que tem como objeto um bem usado ou que foram individualmente elaborados entre as partes. Portanto, a maioria dos contratos de compra e venda do dia-a-dia enquadramse na definição do contrato de compra e venda de bens de consumo ${ }^{137}$.

As normas são cogentes, quer dizer, não podem ser excluídas do contrato por consenso das partes ${ }^{138}$. A limitação da responsabilidade por determinados vícios dá-se pela descrição e denominação da coisa vendida, p. ex. como "carro pronto para o ferro-velho" (schrottreif) em vez de "carro usado"139.

\footnotetext{
134 BITIER, Georg; MEIDT, Eva. Op. cit. p. 2123.

335 SCHWAB, Dieter. Op. cit. p. 6. A reforma do direito das obrigaçōes supera dificuldades desnecessárias de construçăo, como coloca BÜDENBENDER, Utrich. Op. cit. p. 317.

136 As noçōes de "consumidor" e "fomecedor" foram inseridas antes no BCB. Para uma análise detalfłada, veja MARQUES, Cláudia Lima, Normas de proteção do consumidor (especialmente no comércio eletrônico) oriundas da União Européia e o exemplo de sua sistematizaçäo no Código Civil alemão de 1896-notícia sobre as profundas modificações no BGB para inchir a figura do consumidor, Revista de Direito Privado. Săo Paulo: Revista dos Tribunais, v, 4, 2000, p. 50 e seg.

is GURSKY, KarH-Heinz. Op. cit. p. 48.

:38 PREBB, Bernd. Op. cit. p. 185. SCHWAB, Dieter. Op. cit. p. 6.

139 PFEIFFER, Thomas. Systemdenken im neuen Leistungsstörungs- und Gewährleistungsrecht. Zeitschrift für das gesamte Schuldrecht. Recklinghausen: ZAP, v. 1, 2002. p. 32.
} 
Em parte, as regras correspondem às normas sobre o controle de condições gerais do contrato, colocadas no $\$ 309 \mathrm{n}^{\circ} 8$ b), deixando somente espaço para a limitação do direito à indenização, se for combinado individualmente entre as partes e para a redução de prazos de prescrição, $\S 475$, inciso [1l. De alta importância são as regras sobre a inversão do ônus de prova e sobre a responsabilidade aumentada do fornecedor em contratos de compra e venda à distância (Verbrauchsgüter-Versendungskauf). $\mathrm{O} \$ 476$ presume que um vício que aparece durante um prazo de seis meses depois da entrega da coisa já esteve presente no momento da entrega ${ }^{\uparrow 40}$. Isto facilita a prova para o consumidor, pois, sob estas circunstâncias, o fornecedor tem que provar que o vício não esteve presente no momento da entrega, o que é chamado de "quase-garantia" (Quasi-Garantie) ${ }^{141}$ Mas esta presunção está limitada pela lei, no próprio $\$ 476$, que se declara não aplicável caso uma presunção deste tipo seja incompatível com a própria coisa ou com o tipo do vício aparecido; pensou-se nos casos de venda de bens usados nos quais o fornecedor tampouco tem condiçōes de saber exatamente a natureza e a qualidade do bem vendido ${ }^{142}$.

A responsabilidade aumentada do fornecedor em contratos de compra e venda à distância dá-se pela exclusão da aplicação do $\$$ 446. Esta regra aplicase no caso em que o vendedor envia a coisa comprada para um lugar determinado pelo comprador ${ }^{143}$ e contribui ao comprador o risco de pioramento casual (zufällige Verschlechterung) do bem no caminho ${ }^{144}$. Como o $\$ 474$, inciso II determina a inaplicabilidade do $\$ 446$ numa relação contratual entre um fornecedor e um consumidor, o fornecedor é responsável pelo fornecimento da coisa no lugar indicado sem a possibilidade de invocar o pioramento casual (zufällige Verschlechterung) do bem ${ }^{145}$.

Com esta ampliação dos direitos do consumidor, o último fornecedor na cadeia de consumo corre o risco, agora aumentado, de responder por vícios do produto ${ }^{146}$. Muitas vezes, o último fornecedor nāo causou o vício, mas o

30 BÜLOW, Peter; ARTZ, Markus. Verbraucherprivatrecht. Heidelberg: C. F. Müller, 2003. p. 122. GSELL, Beate. Op. cit. p. 73 .

341 SCHWAB, Dieter. Op. cit. p. 6

142 SCHELLHAMMER alerta que esta timitaçāo nào é exata o suficiente e traz novas dúvidas. Compare SCHELLHAMMER, Kurt. Op. cit. p. 246.

is Pensa-se no caso que o vendedor manda o bem pelo correio para o domicílio do comprador.

¡ ${ }^{4}$ BULLOW, Peter; ARTZ, Markus. Op. cit. p. 123.

is Esta distribuição do risco foi previstà, inicialmente, para todos os contratos de compra e venda, mas depois limitada às contratos de compra e venda de bens de consumo à longa distância. Veja MOTSCH, Richard. Risikoverteilung im allgemeimen leistungsstörungsrecht, Juristenzeitung. Tübingen: Mohr Siebek, v. 9, 2001. p. 430.

146 Na visảo alemât, os direitos oriundos de um contrato 5 ão realizados entre as partes; contratando o consumidor com o útimo fornecedor na cadeia de consumo, é este último fornecedor contra quem o consumidor realiza seus direitos. 
produtor ou um outro fornecedor é o responsável por ele ${ }^{147}$. O art. 4 da Diretiva sobre a compra e venda de bens de consumo ${ }^{148}$ exige, portanto, a instalação de um mecanismo que permita transferir os custos para o elo da cadeia de fornecimento no qual o vício foi causado. O legislador alemão, para internalizar o art. 4, criou o assim chamado "Händlerregress" (recurso de regresso do fornecedor) nos $\S \S 478$ e $479 \mathrm{BGB} / 2002$. O paradigma central desta nova pretensão de um fornecedor contra um outro é o fato de que a pretensão segue a cadeia de fornecimento ${ }^{i 49}$. Isto significa que o último fornecedor não tem uma pretensão dirigida diretamente contra o fornecedor que causou o vício, mas ele tem que dirigir-se à outra parte do seu contrato, que é o penúltimo fornecedor. Este penúltimo fornecedor, se não causou o vício, dirige-se ao fornecedor de quem ele tinha adquirido a coisa viciada; assim cria-se uma cadeia de responsabilidade, que é um reflexo da cadeia de fornecimento ${ }^{150}$. $O$ conteúdo da prestação do recurso do fornecedor depende do direito realizado pelo consumidor. Se o consumidor exigiu adimplemento tardio, o fornecedor tem direito a pagamento dos gastos causados pelo adimplemento tardio. Se o consumidor chegou a mudar o preço ou rescindir do contrato, o fornecedor ganha o direito de mudar o preço ou rescindir contra o seu contratante, que forneceu a coisa viciada para ele ${ }^{151}$.

A reforma do direito das obrigações não causou somente mudanças importantes nos contratos de compra e venda, mas também trouxe alterações para outros tipos de contratos, como o de empreitada (Werkvertrag) ou de viagem (Reisevertrag). No início da discussão sobre a reforma, uma grande parte das normas sobre estes dois tipos de contrato devia ser reformada ${ }^{152}$, mas o legislador acabou aplicando somente mudanças menores ${ }^{15.3}$. Mais uma vez, a intenção de simplificar e trazer mais transparência por meio da harmonização das diferentes normas do BGB apadrinhou a elaboração das regras para o contrato de empreitada. Como o contrato de compra e venda serve de modelo para todos os demais contratos na parte especial do direito das obrigaçôes, pretendeu-se harmonizar as normas do contrato de empreitada com as do

147 SCHMIDT-RÄNTSCH, Jürgen. Op. cit, p. 305, ponto 949. BÜLOW, Peter; ARTZ, Markus. Op. cit. p. 125.

s48 Parte da doutrina duvida a competência da Comunidade Européia para exigir tal regra. Compare BRÜUGEMEER, Gert; REICH Norbett. Op. cit. p. 221.

${ }_{349}$ Veja a análise cia Diretiva de BRUGCGMEIER, Gert. Zur Reform des deutschen Kaufrechts. Juristenzeitung. Tübingen: Mohr Siebek, v.11, p. 533.

${ }_{150}$ Sobre as vantagens desta construção, consulte ERNST, Wolfgang; GSELL, Beate. Kritisches zum Stand der Schuldrechtsmodernisierung. Zeitschrift für Wirtschaftsrecht. Köln: RWS, v. 32, 2001, p. 1394.

15: Critico quanto ao fato que o direito do fomecedor depende do direito realizador pelo consumidor ERNST, Wolfgang; GSELL, Beate. Op. cit. p. 1396. Com vários exemplos, BRÜGGEMEIER, Gert. Op. cit. p. 534 e seg.

152 O projeto é descrito por DAUNER-LIEB, Barbara. Op. cit. p. 14.

153 Isto é a conclusảo de SCHUDNAGIES no seu trabalho sobre o contrato de empreitada depois da reforma. Veja SCHUDNAGIES, jörg. Das Werkvertragsrecht nach der Schuldrechtsreform. Neue Juristische Wochenschrift. München: C. H. Beck, v. 6, 2002. p. 400. 
contrato de compra e venda ${ }^{154}$. Portanto, encontram-se, nos contratos de empreitada, definições muito parecidas com as do contrato de compra e venda quanto à noção do vício e direitos secundários iguais (adimplemento tardio, rescisāo, abatimento do preço, indenizaçāo) ${ }^{155}$. Uma diferença importante no direito ao adimplemento tardio é o fato de que o empreiteiro, e não o dono da obra, pode decidir se ele quer consertar a obra já produzida (Nachbesserung) ou se prefere produzir uma nova obra (Neuherstellung). Estabelecendo este direito de escolher a maneira do adimplemento tardio, o legislador seguiu a jurisprudência que, já antes, tinha estabelecido tal direito ${ }^{156}$.

Além dos quatro direitos adaptados do contrato de compra e venda, o dono da obra tem a possibilidade de ele mesmo consertá-la e cobrar do empreiteiro por isto, a assim chamada "Selbstvornahme", $\S 637^{157}$. Este direito somente pode ser exercido depois de colocar um prazo para o empreiteiro adimplementar tardio; ao contrário do antigo BGB/1900, já não se exige a mora do empreiteiro ${ }^{158}$. Além disso, o empreiteiro tem que pagar um adiantamento pelos custos presumidos do dono da obra, caso for solicitado, $\S 637$, inciso 111 .

Nos contratos de viagem, o maior impacto nota-se na reforma dos prazos da prescrição. Em comparação aos contratos de compra e venda, os prazos de prescrição foram aumentados; antes, pretensões oriundas de um vício prescreviam em seis meses. Como o prazo de prescriçāo foi resumido a dois anos em todos os outros tipos de contratos, o legislador não viu a necessidade de manter um prazo mais curto para os contratos de viagem ${ }^{159}$. Uma parte da doutrina critica esta argumentação, alertando que a situação num contrato de viagem é diferente da de um contrato de compra e venda ou de empreitada. Na prova do vício de uma viagem, o fator tempo é de alta importância, pois já não se pode analisar o objeto do contrato. Uma viagem assemelha-se mais à prestação de um serviço que ao fornecimento de um objeto, o que faz com que um prazo relativamente curto para reclamações diga respeito aos interesses das partes. O prazo de seis meses apresentava bons resultados e, portanto, devia ser mantido ${ }^{160}$.

\footnotetext{
354 SCHWAB, Dieter. Op, cit, p. 7. SCHUDNAGIES, Jörg. Op. cit. p. 396.

155 Compare SCHMIDT-RÄNTSCH, Jürgen. Op. cit. p. 315 , ponto 975.

156 SCHUDNAGIES, Jörg. Op. cit. p. 397. GURSKY, Kari-Heinz concorda com a dectsão do legislador analisando que ela faz sentido do ponto de vista econômico, pois o empreiteiro escolherá a maneira de custos mais favoráveis. GURSKY, KarlHeinz, Op. cit. p. 134.

157 WIESER, Eberhard. Eine Revolution des Schuldrechts. Neue Juristische Wochenschrift. München: C. M. Beck, v.2, 2001. p. 23 .

353 SCHWAB, Dieter. Op. cit.p. 7 .

${ }^{159} \mathrm{FÜHRICH}$, Ernst. Reisevertragsrecht nach modernisiertem Schuldrecht. Neue luristische Wochenschrift. München: $\mathrm{C}$. $\mathrm{H}$. Beck, v. 15, 2002. p. 1082 eseg.

${ }^{160}$ Compare FÜHRICH, Emst. Op. cit. p. 1083.
} 


\section{B. 2 A integração de leis satélites}

Para completar a reforma, o legislador queria incorporar várias leis satélites no BGB. O debate sobre se deveria se fazer tal incorporação e, caso sim, como fazer, foi um dos pontos mais debatidos no processo da reforma. Pois não havia pressão nenhuma por parte do Direito comunitário ${ }^{161}$ ou por razões sistemáticas de colocar as leis satélites no $\mathrm{BGB}^{162}$. Portanto surgiam posições que defendiam a exclusão desta parte da reforma, sobretudo devido à enorme pressão de tempo ${ }^{163}$. Os apoiadores da integração alegaram que $\mathrm{a}$ reforma do direito das obrigações traria uma chance única de reconstruir a unidade do direito civil no Código central deste ramo de direito, no $\mathrm{BGB}^{164}$. Antes da reforma, não era possível dar respostas às perguntas jurídicas do diaa-dia somente usando o $B G B$, mas precisava-se do conhecimento de várias outras leis. Este "crescimento incontrolado" (Wildwuchs) das leis satélites danificava a sistemática do ordenamento jurídico civil. Colocando estas leis satélites no BGB, o legislador diminuiria o risco de o aplicador de direito não reparar normas existentes e facilitaria, também para o jurista estrangeiro, a aplicação do direito civil alemão ${ }^{165}$.

As vozes críticas alertaram que a mera colocação das leis satélites no BGB não simplificaria a aplicação de direito. Primeiro, porque tinha que ser realizada pela criação de vários sub-parágrafos, o que não facilitaria o uso do Codex. Muito mais pesava o argumento de que a integração exigia a harmonização das leis satélites entre si e a sua adaptação às normas do $B \mathrm{BB}^{166}$. Muitas das leis satélites provêm de Diretivas que usam uma linguagem e terminologia diferente do legislador alemão de 1900. Além disso, era muito provável que o legislador comunitário promulgaria novas diretivas, mudando as normas das leis satélites. A internalização destas novas diretivas seria muito mais fácil se as normas afetadas estivessem em leis satélites ${ }^{167}$.

Ainda assim, o legislador optou pela integração de várias leis e colocou as seguintes leis no $B G B^{168}$ :

\footnotetext{
361 O direito comunitario obriga os Estados-Membros a intemalizar as Diretivas promulgadas mas deixa com eles a decisăo como e por qual meio a internalização e feita. Não há problema nenhuma de internalizar uma Diretiva numa lei satélite.

i62 ART7, Markus. Schuldrechtsmodernisieurng 2001/2002 - Integration der Nebengeseze in das BGB. Juristische Schulung. München: C. H. Beck, v. 6, 2002, p. 528. ${ }^{163}$ Veja PALM, Heinz. Op. cit. p. 432.

164 SCHMIDT-RÄNTSCH apud PALM, Heinz. Op. cit. p. 432.

165 HELDRICH, Andres. Op. cit. p. 2522.

166 Compare ZIMMERMANN, Reinhard. Op. cit. p. 179.

(6) PAl.M, Heimz. Op. cit. p. 432.

its Uma sinopse detalhada sobre a transterência das nomas encontra-se em LORENZ, Stephan. RIEHM, Thomas. Op. cit. p. 80 , ponto 155 e seg.
} 
- Lei sobre condições gerais do contrato (Gesetz über Allgemeine Geschäftsbedingungen - AGBG) nos $\$ \S 305$ $310 \mathrm{BGB} / 2002$;

- Lei sobre o direito ao arrependimento na venda de produtos na porta (Haustürwiderrufsgesetz - HWiG) nos $\S \S 312,312$ a) $\mathrm{BGB} / 2002$;

- Lei sobre compra e venda à distância (Fernabsatzgesetz FernAbsG) nos $\$ \$ 312$ b) - d) $B G B / 2002$;

- Lei sobre a multipropriedade (Teilzeitwohngesetz - TzWG) nos $\S \S 481-487 \mathrm{BGB} / 2002$

- Lei sobre os créditos de consumo (Verbraucherkreditgesetz - VerbrkrG) nos $\$ \$ 491$ - $506 \mathrm{BGB} / 2002$.

Além disso, novos deveres de informar no comércio eletrônico foram estabelecidos no $\$ 312$ e) para internalizar os artigos 10 e 11 da Diretiva sobre comercio eletrônico ${ }^{169}$. Figuras jurídicas que eram semelhantes em todas as leis foram unificadas, como por exemplo, o direito ao arrependimento nos contratos de consumo (Widerrufsrecht bei Verbraucherverträgen) ${ }^{170}$

Entre as leis integradas, destaca-se a lei sobre condições gerais do contrato, cujo teor agora consta da parte geral do direito das obrigaçōes. ${ }^{171} \mathrm{~A}$ maioria da doutrina alemã sugeriu a colocação na parte geral do $B G B^{172}$. O legislador queria somente aplicar mudanças menores, mas acabou inserindo aspectos importantes. $O \$ 305$ inciso $1 / n^{\circ} 2$ traz uma nova regra quanto ao uso de condiçōes gerais do contrato no caso de a outra parte ser deficiente física. Sob estas circunstâncias, a situação especial da outra parte tem que ser respeitada, e as condições gerais do contrato têm que ser colocadas à disposição de maneira que possam ser percebidas apesar do déficit corporal.

A lei sobre condiçōes gerais do contrato compreendia uma cláusula geral, que agora está no $\$ 307$ inciso I frase $2 \mathrm{BGB} / 2002$. Esta serve para abranger todas as cláusulas abusivas que não podem ser anuladas por regras especiais. Estabelecese, em primeiro lugar, que uma cláusula é nula se ela prejudica a outra parte,

769 Como observa ARTZ, esta norma traz um conteúdo (Regelungsgehalt') até então desconhecido pelo direito alemão. ARTZ, Markus. Op. cit. p. 528.

m) Compare KOPPENFELS, Katharina von. Op. cit. p. 1360 e seg. HUBER, Peter. FAUST, Florian. Op. cit. p. 456, ponto 5.

171 Uma análise abrangente desta lei e sua integraçăo no BGB/2002 faz STOFFELS, Markus. AGB-Recht. München; C. H. Beck, 2003. p. 22 eseg.

i72 Esta idéia fol apresentada por PFEIFFER, Thomas num congresso sobre a reforma do direito das obrigações. Compare o relatório do congresso por JAKOBS, Horst Heinrich. Op. cit. p. 29. Seguindo a opinião de Pfeiffer, STOFFELS, Markus. Op. cit. p. 25, ponto 60 . 
afetando a boa-fé objetiva. Em segundo lugar, determina que um prejuízo da outra parte também pode se dar pelo fato de que a cláusula não está formulada de maneira clara e entendível e, com isto, não é transparente. A doutrina discutia a questão se uma cláusula não formulada de maneira clara e entendivel prejudica, por si, a outra parte ou se a ocorrência de um dano é necessário para anular a cláusula em questão. Inicialmente, o legislador buscou estabelecer que uma cláusula fosse nula somente por causa da sua não-transparência, mas acabou exigindo um dano para evitar que o campo de aplicação seja extrapolado ${ }^{173}$.

Um problema central da adaptação do direito das condições gerais do contrato ao novo direito da perturbação do contrato deu-se pela pergunta se é possivel excluir a responsabilidade por negligência simples (einfache Fahrlässigkeit), aplicando condiçōes gerais do contrato ${ }^{174}$. Os $\S \S 305-310 \mathrm{BGB} /$ 2002 não recepcionaram o $\$ 11 n^{\circ} 8$ b) $A G B G$, que proibiu a exclusão da responsabilidade nos casos de mora e impossibilidade. Argumentava-se que tal proibição não respeitava as necessidades em situações diárias, p. ex., na compra e venda de um carro usado por consumidores que usam um formulário com condições gerais do contrato ${ }^{175}$. Além disso, existia jurisprudência que considerava nula uma cláusula de exclusão de responsabilidade por negligência simples, caso esta atingisse deveres centrais (Kardinalpflichten) do contrato ${ }^{176}$; esta jurisprudência pode ser usada também sob o regime do BGB/2002 para evitar que a possibilidade de liberar-se da responsabilidade por negligência simples prejudique o consumidor ${ }^{177}$. Ainda é de ser mencionado que a cláusula geral do $\$ 307$ inciso II BGB/2002 pode ser aplicada, sobretudo nos contratos nos quais uma parte é um consumidor, para declarar nula um cláusula que limita a responsabilidade do usuário ${ }^{178}$.

173 ARTZ, MarkLs. Op. cit. p. 529. WESTPHALEN chega a mesma conclusäo com base na interpretaşäo do texto do 3307 inciso 1 frase 2, que usa a palavra "pode", o que deixa claro que não qualquer intransparência tem como conseqüuencia a nulidade da cláusula. WESTPHALEN, Friedrich Grafv.. AGB-Recht ins BGB - Fine erste Bestandsaufnahme. Neue Juristische Wochenschtift. München: C. H. Beck, v. 1, 2002. p. 17.

374 Estas cáusulas săo chamadas de "Freizeichnungsklauseln". Uma análise profunda com várias suggestões dognáticas dá WESTPHALEN, Friedrich Graf v. Op. cit, p. $22 \mathrm{eseg}$.

35. É importante lembrar que o direito alemäo distingue entre "Unternehmer" (fornecedor) e "Verwender" (usuário). A primeira noçio define uma pessoa que atua de maneira profissionat no mercado, enquanto a segunda determina a pessoa que usa condiçŏes gerais do contrato. O usuário pode ser um consumidor se ele usa condiçôes gerais pré-formulados por um terceiro.

176 VejáARTZ, Markus. Op. cit. p. 531.

:7 STOFFELS, Markus. Op. cit. p. 473, ponto 976.

i78 WESTPHALEN, Friedrich Graf v.. Op. cit. p. 23. 
Ao contrário da lei sobre as condições gerais do contrato, a integração da lei sobre os créditos de consumo (Verbraucherkreditgesetz) causou problemas para o legislador e acabou acarretando mudanças de lei provavelmente não intencionadas 179 . A Verbraucherkreditgesetz não foi colocada "en bloc" no novo $\mathrm{BGB}^{180}$, mas reorganizada do ponto de vista sistemático; isto teve como conseqüência que as normas, antes unidas na lei, encontram-se espalhadas pelo novo $\mathrm{BGB}^{181}$. Quanto ao conteúdo, destacam-se duas novidades. A primeira foi inserida somente nos momentos finais do processo legislativo e enseja que uma prorrogação para a celebração de um contrato de crédito de consumo somente pode ser concedida por forma escrita. Antes, a jurisprudencia não exigia a forma escrita para tal prorrogação. A segunda novidade acaba com a discussão doutrinária sobre a questão de se o consumidor pode prescindir da proteção da lei sobre créditos de consumo por meio de uma declaração unilateral. O novo BGB esclarece que o consumidor não tem a possibilidade de prescindir desta proteção legal ${ }^{182}$.

A integração da lei sobre o direito ao arrependimento na venda de produtos na porta, da lei sobre a compra e venda à distância e da lei sobre a multipropriedade não trouxe mudanças maiores para as matérias reguladas por estas leis. Os deveres no comércio eletrônico sāo novos no ordenamento jurídico alemão e foram regulados no $\$ 312$ e) BGB. É importante ressaltar que a norma exige que uma parte do contrato seja um fornecedor sem estabelecer que a outra seja um consumidor ${ }^{183}$; portanto, aplica-se na área do B2B (business-to-business), bem como na área do B2C (business-to-consumer) ${ }^{184}$.

São regulados os casos nos quais o cliente acessa uma oferta virtual (normalmente o site do fornecedor) e, com base nesta oferta, faz sua encomenda; não é regulada a situação em que as partes elaboram um contrato por meios eletrônicos de comunicação, p. ex. elaboração de um contrato via e-mail. Além disso, somente o contrato tem que ser celebrado on line; o cumprimento da prestação pode ser efetuado pelo caminho tradicional, quer dizer, off line. Vários deveres do fornecedor foram colocados na lei, entre eles, a obrigação de oferecer uma possibilidade de corrigir a encomenda antes de mandá-la, uma confirmação da encomenda recebida por e-mail e a possibilidade de acessar as condiçōes gerais do contrato. O 312 e) inciso I frase 2 BGB/2002

\footnotetext{
179 SCHWAB, Diter. Op. cit. p.8.

in Sobre as vantaggens de uma colocação "en bloc", veja. DÄUBER-GMELN, Herta. Op. cit. p. 2286.

18: Há regras oriundas da lei sobre os créditos de consumo nos \$\$ 488-507, que estäo divididos em três sub-títulos. Além disso, o legisiador colocou umas regras especiais nos $\$ \S 655$ a) $-\mathrm{e})$.

182 Compare ARTZ, Markus. Op. cit. p. 534.

183 A lei fala, de maneira geral, em "cliente" (Kunde).

1 13 Ainda assim, no B2B, as regras do $\$ 312$ e) podem ser excluidas do contrato por acordo das partes, $\$ 312$ e) incisoll, frase 2. Compare KROPHOLIER, Jan. Op. cit. p. 204, ponto 2 .
} 
é de alta importância para o comércio eletrônico em geral e para a dogmática da manifestaçāo de vontade, pois determina que uma manifestaçāo de vontade declarada por meio eletrônico é considerada recebida quando o recipiente pode acessá-la sob circunstâncias normais ${ }^{185}$.

\section{Conclusões}

Descrever, de maneira detalhada, as várias mudanças e novas tendências no novo direito das obrigações na Alemanha é uma tarefa cujo cumprimento resultaria num livro de centenas de páginas. Portanto, a intenção deste artigo não foi informar o leitor sobre a reforma inteira, mas sim mostrar os pontos altos e mais discutidos, bem como apontar abrangentemente para as mudanças.

Durante o processo legislativo, a doutrina discutiu fortemente sobre os prós e contras das diferentes versões das normas a serem reformadas. Um exemplo para isto é a discussão travada entre ALTMEPPEN e CANARIS sobre a questão da indenização em vez da prestação (Schadensersatz statt der Leistung), regulada no novo $\$ 281 \mathrm{BGB} / 2002^{186}$. Por causa destas críticas, professores de direito civil na Alemanha juntaram-se e assinaram uma manifestação comum (Gemeinsame Erklärung), na qual pediram à então Ministra da Justiça para adiantar a "solução grande" e restringir a reforma de 2002 à internalização obrigatória das Diretivas ${ }^{187}$. Mesmo assim, a Ministra não abriu mão da solução grande, que está, desde 01 de janeiro de 2002, em vigor na Alemanha ${ }^{188}$.

O novo direito das obrigações traz novos paradigmas e visöes para o conceito de "contrato" e, com isto, novas dúvidas e questões que doutrina e prática têm que enfrentar juntos. Com certeza, o BGB manteve seu alto grau de abstração e o método de colocar, numa parte geral, as regras, que depois devem ser usadas na aplicação das normas da parte especial. Influências do direito comunitário e internacional encontram-se agora no cerne do Código Civil alemão, reforçando, novamente, a proteção a contratantes que estão numa posição mais fraca, como os consumidores. Com tudo isto, o novo BGB/2002 enfrenta a realidade pós-moderna e traz novas soluções para as questões

185 O texto diz: "(...) wenn sie die Parteien unter gewöhnlichen Umständen abrufen können.". Sobre o $\$ 312$ e) BGB/2002, veja ARTZ, Markus. Op. cit. p. 534 e seg.

186 Compare a discussão nas seguintes contribuições: ALTMEPPEN, Holger. Schadensersatz wegen Pflichtverletzung - Ein Beispiel für die Überhastung der Schuldrechtsreform. Der Betrieb. Düsseldorf: Handelsblatt v. 21, 2001.p. 1131 e Nochmals: Schadensersatz wegen Pflichtverletzung, anfängliche Unmöglichkeit und Aufwendungsersatz im Entwurf des Schuldrechtsmodernisierungsgesetzes. Der Betrieb. Düsseldorf: Handelsblatt, v. 34, 2001.p. 1822. CANARIS, ClausWithelm. Schadensersatz wegen Pflichtverletzung, anfängliche Unmöglichkeit und Aufwendungsersatz im Entwurf des Schuldrechtsmodernisierungsgesetzes. Der Betrieb. Düsseldorf: Handelsblatt, v. 34, 2001 . p. 1816.

187 Compare ALTMEPPEN, Holger. Op. cit. p. 1822.

186 Compare os seus argumentos contra a manifestaçăo de ALTMEPPEN em DÄUBER-GMEUN, Herta. Op. cit. p. 2287. 
jurídicas da atualidade. O fato de ter sofrido críticas em vários pontos e de vários lados - o que é, num sentido individualista e pós-moderno, mais que compreensível - não significa que ele já não seja uma das grandes codificações européias. Muito pelo contrário, a sua grandeza mostra-se na habilidade de enfrentar estas críticas e continuar progredindo com ou contra elas.

\section{Bibliografia}

ALTMEPPEN, Holger. Nochmals: Schadensersatz wegen Pflichtverletzung, anfängliche Unmöglichkeit und Aufwendungsersatz im Entwurf des Schuldrechtsmodernisierungsgesetzes. Der Betrieb. Düsseldorf: Handelsblatt, v. 34, 2001. p. 1821-24.

. Schadensersatz wegen Pflichtverletzung - Ein Beispiel für die Überhastung der Schuldrechtsreform. Der Betrieb. Düsseldorf: Handelsblatt, v. 21, 2001. p. 11311133.

ARTZ, Markus. Schuldrechtsmodernisieurng 2001/2002 - Integration der Nebengesetze in das BGB. Juristische Schulung. München: C. H. Beck, v. 6, 2002. p. 528-535.

BITTER, Georg; MEIDT, Eva. Nacherfüllungsrecht und Nacherfüllungspflicht des Verkäufers im neuen Schuldrecht. Zeitschrift für Wirtschaftsrecht. Köln: RWS, v. 48, 2001. p. 2114-2124.

BRÜGGEMEIER, Gert. Zur Reform des deutschen Kaufrechts. Juristenzeitung. Tübingen: Mohr Siebek, v.11, p. 529-538

; REICH, Norbert. Europäisierung des BGB durch große Schuldrechtsreform? Stellungnahme zum Entwurf eines Schuldrechtsmodernisierungsgesetzes. Betriebsberater. Heidelberg: Recht und Wirtschaft, v. 5, 2001. p. 213-222.

BÜDENBENDER, Uirich. Das Kaufrecht nach dem Schuldrechtsreformgesetz (Teil 1). Deutsches Steuerrecht: Wochenschrift für Steuerrecht, Wirtschaftsrecht und Betriebswirtschaft. München: C. H. Beck, v. 8, 2002. p. 312-318.

BÜLOW, Peter; ARTZ, Markus. Verbraucherprivatrecht. Heidelberg: C. F. Müller, 2003. $173 \mathrm{p}$.

BÜTTNER, Helmut. Schuldrechtsmodernisierung und Familienrecht, insbesondere Verjährung, Verwirkung und Verzug. Zeitschrift für das gesamte Familienrecht. Düsseldorf: Handelsblatt, v. 6, 2002. p. 361-366.

CANARIS, Claus-Wilhelm. Das allgemeine Leistungsstörungsrecht im Schuldrechtsmodernisierungsgesetz. Zeitschrift für Rechtspolitik. München: C. H. Beck, v. 8, 2001. p. 329-336.

. Schadensersatz wegen Pflichtverletzung, anfängliche Unmöglichkeit und Aufwendungsersatz im Entwurf des Schuldrechtsmodernisierungsgesetzes. Der Betrieb. Düsseldorf: Handelsblatt, v.34, 2001. p. 1815-1821.

. Sondertagung Schuldrechtsmodernisierung: Die Reform des Rechts der Leistungsstörungen. Juristenzeitung. Tübingen: Mohr Siebeck, v. 9, 2001. p. 499528. 
DÄUBLER-GMELIN, Herta. Die Entscheidung für die sogenannte Große Lösung bei der Schuldrechtsreform. Neue Juristische Wochenschrift. München: C. H. Beck, v. 32, 2001. p. 2281-2289.

DAUNER-LIEB, Barbara. Die geplante Schuldrechtsmodernisierung - Durchbruch oder Schnellschuss?. Juristenzeitung. Tübingen: Mohr Siebeck, v. 1, 2001. p. 8-18.

EIDENMÜLLER, Horst. Zur Effizienz der Verjährungsregeln im geplanten Schuldrechtsmodemisierungsgesetz. Juristenzeitung. Tübingen: Mohr Siebek, v. 6, 2001. p. 283-287.

ERNST, Wolfgang. Schuldrechtsreform 2001/2002: Zum Diskussionsentwurf des Schuldrechtsmodernisierungsgesetzes. Zeitschrift für Rechtspolitik. München: C. H. Beck, v. 1, 2001. p. 1-11.

. GSELL, Beate. Kritisches zum Stand der Schuldrechtsmodernisierung. Zeitschrift für Wirtschaftsrecht. Köln: RWS, v. 32, 2001. p. 1389-1403.

FISCHER, Michael. Der Ausschluss der Leistungspflicht im Falle der Unmöglichkeit im Entwurf des Schuldrechtsmodernisierungsgesetzes ( $\$ 275$ BGB RegE). Der Betrieb. Düsseldorf: Handelsblatt, v. 36, 2001. p. 1923-1926.

FÜHRICH, Ernst. Reisevertragsrecht nach modernisiertem Schuldrecht. Neue Juristische Wochenschrift. München: C. H. Beck, v. 15, 2002, p. 1082-1084.

GRUNEWALD, Barbara. Vorschläge für eine Neuregelung der anfänglichen Unmöglichkeit und des anfänglichen Unvermögens. Juristenzeitung. Tübingen: Mohr Siebek, v. 9, 2001. p. 433-436.

GSELL, Beate. Kaufrechtsrichtlinie und Schuldrechtsmodernisierung. Juristenzeitung. Tübingen: Mohr Siebek, v. 2, 2001. p. 65-75.

GURSKY, Karl-Heinz. Schuldrecht: Besonderer Teil. 4. ed. Heidelberg: C. F. Müller, 2002. 284 p.

HAAS, Lothar; MEDICUS, Dieter; ROLLAND, Walter; SCHÄFER, Carsten; WENDTLAND, Holger. Das neue Schuldrecht. München: C. H. Beck, 2002, p. 13

HAMMEN, Horst. Zerschlagt die Gesetzestafeln nicht! Wertpapiermitteilungen: Zeitschrift für Wirtschafts- und Bankrecht. Frankfurt am Main: Herausgebergemeinschaft Wertpapiermitteilungen, v. 29, 2001. p. 1357-1359.

HELDRICH, Andreas. Ein zeitgemäßes Gesicht für unser Schuldrecht. Neue Juristische Wochenschrift. München; C. H. Beck, v. 35, 2001. p. 2521-2523.

HEINRICHS, Helmut. Entwurf eines Schuldrechtsmodernisierungsgesetzes: Neuregelung des Verjährungsrechts. Betriebsberater. Heidelberg: Recht und Wirtschaft, v. 28, 2001. p. 1417-1423.

HEB, Burkhart. Die Übergangsregelungen zum Schuldrechtsmodernisierungsgesetz. Deutsches Steuerrecht: Wochenschrift für Steuerrecht, Wirtschaftsrecht und Betriebswirtschaft. München: C. H. Beck, v. 11, 2002. p. 455-461.

HONSELL, Heinrich. Einige Bemerkungen zum Diskussionsentwurf eines Schuldrechtsmodemisierungsgesetzes. Juristenzeitung. Tübingen: Mohr Siebeck, v. 1, 2001. p. 18-21.

. Die EU-Richtlinie über den Verbrauchsgüterkauf und ihre Umsetzung ins BGB. Juristenzeitung. Tübingen: Mohr Siebeck, v. 6, 2001. p. 278-283. 
HUBER, Peter; Faust, Florian. Schuldrechtsmodernisierung: Einführung in das neue Recht. München: C. H. Beck, 2002. 529 p.

JAEGER JUNIOR, Augusto. Das nete brasilianische Bürgerliche Gesetzbuch und das Unternehmensrecht. Em: JAYME, Erik; SCHINDLER, Christian (Org.). Portugiesisch - Weltsprache des Rechts: Studien, Referate, Gutachten zu den Rechtssystemen von Angola, Brasilien, Osttimor und Portugal. Aachen: Shaker, 2004. p. 217-235.

JAYME, Erik; SCHINDLER, Christian (Org.). Portugiesisch - Weltsprache des Rechts: Studien, Referate, Gutachten zu den Rechtssystemen von Angola, Brasilien, Osttimor und Portugal. Aachen: Shaker, 2004. 438 p.

JAKOBS, Horst Heinrich. Tagungsbericht Schuldrechstmodernisierung: Impressionen von einem Symposium. Juristenzeitung. Tübingen: Mohr Siebeck, v. 1, 2001. p. 27-30.

KNÜTEL, Rolf. Zur Schuldrechtsreform. Neue Juristische Wochenschrift. München: C. H. Beck, v. 35, 2001. p. 2519-2521.

KOPPENFELS, Katharina von. Das Widerrufsrecht bei Verbraucherverträgen im BGB eine Untersuchung des $\$ 355$ Abs. 1 BGB-RegE. Wertpapiermitteilungen: Zeitschrift für Wirtschafts- und Bankrecht. Frankfurt am Main: Herausgebergemeinschaft Wertpapiermitteilungen, v. 29, 2001. p. 1360-1369.

KROPHOLLER, Jan. Bürgerliches Gesetzbuch: Studienkommentar. 7. ed. München: C. H. Beck, 2004. 1113 p.

LANGENBUCHER, Katja. Diskussionsbericht zum Vortrag von Claus-Wilhelm Canaris. Juristenzeitung. Tübingen: Mohr Siebek, v. 10, 2001. p. 528-530.

LORENZ, Stephan. Leistungsstörungen: Arbeitshilfe zum neuen Schuldrecht. Anwalt Das Magazin. München, C. H. Beck, v. 12, 2001. p. 12-15.

. Schadensersatz wegen Pflichtverletzung - ein Beispiel für die Überhastung der Kritik an der Schuldrechtsreform. Juristenzeitung. Tübingen: Mohr Siebek, v. 14, 2001. p. 742-745.

; RIEHM, Thomas. Lehrbuch zum neuen Schuldrecht. München: C. H. Beck, 2002. $411 \mathrm{p}$.

MARQUES, Cláudia Lima. Cem nos de Código Civil alemão: O BGB de 1986 e o Código Civil brasileiro de 1916. Revista dos Tribunais. São Paulo: Revista dos Tribunaís, v. 741, 1997. p. 11-37.

; WEHNER, Ulrich. Código Civil alemão muda para incluir a figura do consumidor - renasce o "direito civil geral e social"? Revista de Direito do Consumidor. São Paulo: Revista dos Tribunais, v. 37, 2001. p. 271-277.

- Normas de proteção do consumidor (especialmente no comércio eletrônico) oriundas da União Européia e o exemplo de sua sistematização no Código Civil alemão de 1896 - notícia sobre as profundas modificaçōes no BGB para incluir a figura do consumidor. Revista de Direito Privado. São Paulo: Revista dos Tribunais, v. 4, 2000. p. 50-93.

MATTHEUS, Daniela. Schuldrechtsmodernisierung 2001/2002 - Die Neuordnung des allgemeinen Leistungsstörungsrechts. Juristische Schulung. München: C. H. Beck, v. 3, 2002. p. 209-219. 
MEDICUS, Dieter. Gesetzliche Schuldverhältnisse. 4. ed. München: C. H. Beck, 2003. $190 \mathrm{p}$.

Schuldrecht: Ein Studienbuch. Allgemeiner Teil. 13. ed. München: C. H. Beck, 2002. 412 p.

MOTSCH, Richard. Risikoverteilung im allgemeinen Leistungsstörungsrecht. Juristenzeitung. Tübingen: Mohr Siebek, v. 9, 2001. p. 428-433.

PFEIFFER, Thomas. Systemdenken im neuen Leistungsstörungs- und Gewährleistungsrecht. Zeitschrift für das Gesamte Schuldrecht. Recklinghausen: ZAP, v. 1, 2002. p. 23-32.

OTTO, Hansjörg. Die Grundstrukturen des neuen Leistungsstörungsrechts. Juristische Ausbildung. Berlin: De Gruyter, v. 1, 2002. p. 1-11.

PALM, Heinz. Die Schuldrechtsreform vor dem Hintergrund des Gemeinschaftsrechts. Zeitschrift für Rechtspolitik. München: C. H. Beck, v. 9, 2001. p. 431-433.

PREIB, Bernd. Des einen Freud, des anderen Leid: Neue Rechtslage für Käufer und Verkäufer. Magazin für Computer und Technik. Hannover: Heise, v. 4, 2002. p. 182-185.

RANIERI, Filippo. La nouvelle partie générale du droit des obligations. Revue internacionale de droit comparé. Paris: Francian, v. 54, 2002. p. 941-958.

SCHAPP, Jan. Empfiehlt sich die "Pflichtverletzung" als Generaltatbestand des Leistungsstörungsrechts? Juristenzeitung. Tübingen: Mohr Siebek, v. 11, 2001. p. 583-589.

SCHELLHAMMER, Kurt. Die Haftung des Verkäufers für Sach- und Rechtsmängel Neue Struktur und neuer Mangelbegriff. Monatsschrift für Deutsches Recht. Köln: Dr. Otto Schmidt, v. 5, 2002. p. 241-246.

SCHLECHTRIEM, Peter. Schuldrecht: Allgemeiner Teil. 5. ed. Tübingen: Mohr Siebek, 2003. $362 \mathrm{p}$.

SCHMIDT-RÄNTSCH, Jürgen. Das neue Schuldrecht: Anwendung und Auswirkungen in der Praxis. Köln: Heymanns, 2002. 599 p.

SCHUDNAGIES, Jörg. Das Werkvertragsrecht nach der Schuldrechtsreform. Neue Juristische Wochenschrift. München: C. H. Beck, v. 6, 2002. p. 396-400.

SCHWAB, Martin. Schuldrechtsreform 2001 - Alles wird neu. Juristische Schulung. München: C. H. Beck, v. 3, 2001. p. 311-312.

. Das neue Schuldrecht im Überblick. Juristische Schulung. München: C. H. Beck, v. 1, 2002, p. 1-8.

STOLL, Hans. Notizen zur Neuordnung des Rechts der Leistungsstörungen. Juristenzeitung. Tübingen: Mohr Siebek, v. 11, 2001. p. 589-597.

STOFFELS, Markus. ACB-Recht. München: C. H. Beck, 2003. 589 p.

TEICHMANN, Arndt. Strukturveränderungen im Recht der Leistungsstörungen nach dem Regierungsentwurf eines Schuldrechtsmodernisierungsgesetzes. Betriebsberater. Heidelberg: Recht und Wirtschaft, v. 30, 2001 . p. 1485-1492. 
WESTPHALEN, Friedrich Graf v.. AGB-Recht ins BGB - Eine erste Bestandsaufnahme. Neue Juristische Wochenschrift. München: C. H. Beck, v. 1, 2002. p. 12-25.

WIESER, Eberhard. Eine Revolution des Schuldrechts. Neue Juristische Wochenschrift. München: C. H. Beck, v.2, 2001. p. 121-124.

WITZ, Claude. Pourquoi la réforme et pourquoi s'y intéresser en France? Revue internacionale de droit comparé. Paris: Francian, v. 54, 2002. p. 936-940.

WETZEL, Thomas. Das Schuldrechtsmodernisierungsgesetz - Der große Wurf zum 1.1.2002. Zeitschrift für Rechtspolitik. München: C. H. Beck, v.3, p. 117-126.

WIESER, Eberhard. Eine Revolution des Schuldrechts. Neue Juristische Wochenschrift. München: C. H. Beck, v. 2, 2001. p. 121-124.

ZIMMER, Daniel. Das neue Recht der Leistungsstörungen. Neue Juristische Wochenschrift. München: C. H. Beck, v. 1, 2002. p. 1-12.

ZIMMERMANN, Reinhard. Schuldrechtsmodemisierung? Juristenzeitung. Tübingen: Mohr Siebek, v. 4, 2001. p. 171-181. 